\title{
Vymyslet masopust: město, novodobé slavnosti, tradice a imaginace.
}

\author{
Daniela Stavělová - Matěj Kratochvíl
}

DOI: $10.21104 / C L .2016 .4 .02$

Inventing the Carnival: Contemporary Festivities, Tradition and Imaginaries

\begin{abstract}
Since the beginning of the 1990s we can observe an increasing number of festivities in the Czech Republic which are constructed after a historical shape of the rural carnival. They reveal the needs and intentions of contemporary urban society that manipulates with elements of the carnival in the context of contemporary activities. We focus on the way the structural units of the festivity are selected and appropriated by people within the construction of its contemporary form. The ethnomusicological and ethnochoreological approach enables us to reflect the cognitive process of the participants that makes visible their personal as well as collective experience of the festivity and gives us information about social relationships, culture and collective memory produced together with imaginaries of the time. The qualitative field research took place in several districts of Prague and its suburbs based on relationships between place and interests.
\end{abstract}

Keywords Carnival, festivity, city, tradition, collective memory, music, dance.

Příspěvek byl zpracován s institucionální podporou Etnologického ústavu AV ČR, v. v. i., RVO:68378076.

Contact Doc. Mgr. Daniela Stavělová, CSc., Etnologický ústav AV ČR, v. v. i., Na Florenci 1420/3, 11000 Praha 1, Czech Republic; e-mail: stavelova@eu.cas.cz.

Mgr. Matěj Kratochvíl, Ph.D., Etnologický ústav AV ČR, v. v. i., Na Florenci 1420/3, 11000 Praha 1, Czech Republic; e-mail: kratochvil@eu.cas.cz.

Jak citovat / How to cite Stavělová, Daniela - Kratochvíl, Matěj. (2016). Vymyslet masopust: město, novodobé slavnosti, tradice a imaginace. Český lid 103, 537-568. doi:http://dx.doi.org/10.21104/CL.2016.4.02 
Slavení masopustu je v kalendáři pravidelně se opakujících svátků bezesporu jednou z nejstarších a kulturní pamětí nejdéle přenášenou festivitou, která se houževnatě propojuje s dnešními představami o společném trávení času. Nelze totiž přehlédnout, že od první poloviny 90. let 20. století narůstá na území České republiky počet slavených masopustů zejména ve městech a v příměstských oblastech, a nabízí se otázka, co se stalo v době nebývale široké nabídky kulturního vyžití a názorové rozmanitosti demokratizující se společnosti impulzem pro tak markantní nárůst zájmu o tento, mnohdy ještě tradicí přenášený a nepřetržitě inovovaný jev. Skutečnost, že člověk je homo festivans, ${ }^{1}$ jak výstižně a metaforicky nazvali historikové proces začleňování člověka do vymezených společenských rámců zábavy, ale i věčného řádu a podřízení autoritám, mnohé zodpoví, avšak nás bude i nadále zajímat, proč právě ted', kde a pro koho je slavení masopustu dosud nepřekonanou či spíše znovuobjevenou potřebou společenské komunikace. Jako historický jev svázaný dlouhá staletí s existencí tradiční společnosti, je tato slavnost s ritualizovanými projevy zároveň součástí či výrazem potřeb a představ dnešní společnosti, která s jejími prvky manipuluje v kontextu aktuálního dění. Nás bude zajímat právě tento proces selekce strukturálních jednotek slavnosti masopustu ${ }^{2}$ a jejich přivlastňování při konstruování jeho dnešní podoby řízené intencemi konkrétních lidí. Etnomuzikologický a etnochoreologický přístup dovoluje nahlédnout do kognitivního rozměru aktérů, kteří pomocí tanečního a hudebního repertoáru zviditelňují obraz jejich vlastního, následně kolektivního prožívání momentů slavnosti v opozici k všednodenní skutečnosti. Tento obraz poskytuje zároveň zprávu o sociálních vazbách, kulturní a kolektivní paměti žité v souladu s aktuálními dobovými imaginacemi.

Polem pro provádění kvalitativního výzkumu se stalo prostř̌edí vybraných městských a příměstských částí Prahy a jejího okolí, se zřetelem na jeho provázanost prostřednictvím povědomí o sounáležitosti s místem i společnými zájmy. Výběr a postupné přibírání lokalit se dělo metodou tzv. sněhové koule, tedy nabalování a rozšiřování rádia výzkumného pole na základě postupně se utvářejících referenčních vazeb. Sondou do procesu vzniku a dalšího profilování místní slavnosti bylo pozorování - otevřené i zúčastněné - propojené s vlastní reflexivitou a rozhovory s řadovými aktéry, ale také s iniciátory a vůdčími osobnostmi slavnosti. Výzkum probíhá nepřetržitě od roku 2012, kdy začal být sledován břevnovský masopust, postupně k němu přibývaly další lokality - od roku 2013 masopust v Roztokách, od roku 2016 v Praze na Letné

1 Jako název svého textu použil tento pojem Josef Válka (2000) ve sborníku Slavnosti a zábavy na dvorech a v rezidenčních městech raného novověku; pro charakteristiku středověkého měštana procházejícího rokem ve sledu slavností a usedajícího k práci v nedlouhých přestávkách mezi svátky jej využil Tomáš Borovský (2014).

2 Nemáme na mysli celé období masopustu trvající od Tří králů do Popeleční středy, ale závěrečnou fázi tzv. ostatků či konce masopustu, která bývá se svými performativními prvky předmětem zájmu jak dobových vyobrazení, tak pozdějšího studia. 
a v Buštěhradě u Prahy. Vzhledem k tomu, že jde o dosud probíhající výzkum, bude tato studie prŕspěvkem k vymezení předmětu zkoumání, k jeho tematizaci a úvodem do problematiky současného studia daného jevu rozvíjením jeho paradigmatu pomocí rozmanitých př́istupů kulturní historie a socio-kulturní antropologie. Prostřednictvím auto-etnografie bude také nahlédnuto do procesu konstruování objektu studia probíhajícího za aktivní spolupráce etnomuzikologa a etnochoreologa v rámci společně prováděného výzkumu.

\section{Fenomén slavení masopustu v perspektivě interdisciplinárního studia}

Vzhledem k tomu, že masopust či karneval se stává častým tématem různých oborů, bude dobré se zastavit u skutečnosti, s jakou přistupují ke studiu zmiňovaného jevu některé disciplíny a jaký může být jejich společný zisk při generování klíčových prvků struktury masopustu. Je pochopitelné, že pro pochopení podoby současného slavení masopustu je důležité také porozumění významu historických forem tohoto svátku. Téma masopustu jako součásti studia festivit vnímá a reflektuje zejména kulturní historie. Historikové v rámci medievistických studií zařazují masopust do systému pravidelně se opakujících slavností, ceremonií a rituálů (Nodl - Šmahel 2014; Borovský 2014), v historiografii raně novověkých dějin je mu věnována pozornost zejména v rámci městské kultury (Dülmen 2006). Jako profánní, burleskní a žertovný svátek, vycházející ze zábav kleriků, jej výstižně charakterizoval francouzský historik Jacques Heers (2006: 156), který poukazuje také na vliv aristokratické kultury v podobě knížecích turnajů při slavnostech rytírstva, kde se objevovaly různorodé náměty pojízdné lodi bláznů, orientální prvky či turecké motivy dobývání, groteskní masky se zvířecími hlavami apod. Podle něj karneval navazoval také na burleskní a satirické hry inspirované nedostatky a vadami společnosti, které pořádala města nebo žertovné kompanie. Karneval se tak ve městech „stává výběrovou podívanou poskytnutou ulicí, ale pořádanou aristokracií. Hrají, pochodují, tančí a zpívají ti, kdo se mohou a chtějí prosadit, získat uznání davu.“ (Heers 2006: 189) Zdůrazňuje také význam průvodů související s „potřebou ukazovat se před sousedy, spočítat se a měřit, jak pevná jsou různá pouta solidarity. Průvody jsou jasným a viditelným dokladem velikosti dané skupiny a její soudržnosti. Procesí ukazuje počet a bohatství, přehlídky a hry byly příležitostí zviditelnit své bohatství, dát všem najevo svou sílu a společenskou prestiž.“ (ibid.: 141)

Období slavení masopustu či karnevalu je dále vnímáno (Bachtin 2007; Burke 2005; Muir 2005) jako součást tzv. smíchové kultury se svým groteskním realismem a vlastní logikou, která představuje svět dočasného chaosu, výměny rolí a statusů, ale také jídla, sexu a násilí, tedy jakýsi svět vzhůru nohama nabízející liminální stav bytí, aby mohl být uskutečněn návrat do pevné struktury společenského řádu. Karneval v tomto pojetí poskytuje alternativu 
k normálnímu světu, umožňuje lidem organizovat se podle „vlastních představ“, zdůrazňuje vítězství blázna nad mudrcem, přičemž bláznovství je vnímáno jako stigma, jímž Bůh označil člověka, který se řídí jinými pravidly, než jakými se řídí lidé rozumní (Heers 2006: 113). Toto převrácení hodnot oslavuje pomatence a staví jej na přední místo - často jako děti, protože je stejně bezbranný a nevinný. Jako zdůraznění maskulinity charakterizuje anglický historik Edward Muir (2005: 112) naopak rituály násilí, tj. veřejné předvádění agrese, která je zahalená do rituální formy obřadních zápasů či sportů. Tyto rituály násilí stejně tak jako pravidelně se opakující každoroční „svět naruby“ nabízejí jakousi sublimaci agrese, nesouhlasu či výtek vůči existujícím společenským pravidlům i vůči sobě navzájem, je kontrolovaným ventilem páry ve fingovaných střetech a soubojích, v satiře, obhroublosti, vzájemných nadávkách a obscénnosti vesměs povolených ve vymezeném období. Umožňuje však také rituálním usmrcováním zvířat či odsouzením a symbolickou popravou nekalého živlu očistit společnost od zla - a rozbitím či zpřevracením starých hodnot nastolit řád nový a lepší. Smrt je nahrazena životem a jeho pulz dostává svá pravidla zase přesně do doby, kdy budou zničena stará pravidla a vytvořena nová. Prvky ničení i čistoty jako nahrazení starého novým, zkaženého ryzím, zde mají symbolickou moc, která dává člověku sílu a naději přežít.

Muir (2005: 101-103)) poukazuje také na skutečnost, že karneval si vytvořil jakousi archetypální formu, vůči které mohou být poměřovány i jiné druhy podobných slavností. Prvky karnevalu tak lze, podle něho, najít také v jiných svátcích kalendářního roku, naprríklad v posvícenských slavnostech, ve svátcích kolem stavění májů či pálení svatojánských ohňů v podobě erotických projevů, přemíry jídla a pití nebo v podobě bláznovství jako znaku prostoty i nevinnosti v protikladu se zkažeností. K tomu ještě dodává, že „karneval je příležitostí ke společenskému setkání a pomocí rituálního slovníku umožňuje sdělení myšlenek. Pro jejich pochopení je nutná znalost jazyka festivity. Rituální jazyk umožňuje vytvořit liminální čas a prostor pro alternativní myšlenky a prostor a možnost obrátit běžné hodnoty všedního života naruby.“ (ibid.: 103)

Prvky násilí obsažené ve slavení masopustu bývají antropology vnímány jako rituály obsahující sociální protest (Gluckman 1963; Turner 2004). Vyjadřují protest proti sociálnímu řádu, ale mohou být interpretovány rovněž jako aktivity, které tento řád udržují, tj. jako odstranění obvyklých tabu a omezení zjevně sloužících k jejich posílení. Jakkoli se tyto aktivity zdají být otevřeným protestem proti sociálnímu řádu, ve skutečnosti mají zavedený řád zachovat a dokonce posílit. Max Gluckman (1963: 43) dokonce tvrdí, že v situacích, kde je sociální řád podroben vážné kritice, se „rituály protestu“ neodehrávají. Victor Turner (2004: 115) o rituálech obráceného statusu soudí, že tyto rituály poskytují „extatickou zkušenost“, posílený pocit příslušnosti ke komunitě následovaný vystř́izlivěním a návratem $\mathrm{k}$ běžné sociální struktuře. „Povýšením bezprávných a ponížením mocných se potvrzuje hierarchický 
princip.“V tomto pojetí vystupuje do popředí sociální funkce karnevalových slavností, at' už si to účastníci uvědomují, nebo ne.

V české etnologické literatuře se s tématem masopustu setkáváme nepřetržitě od konce 19. století - od popisných materiálových příspěvků, ${ }^{3}$ přes etnologicky pojaté studie, které sledují masopust jako součást tradičních obyčejů či obyčejové tradice ${ }^{4}$ a zhodnocují zejména výsledky výzkumů po druhé světové válce, kdy stoupl počet slavených masopustů zejména na venkově. Všímají si sociálních funkcí obyčejů a jejich proměn (Tomeš 1977; Frolec - Tomeš 1979) a masopust je řazen ke kulturním aktivitám, které nesou znaky svátečnosti, nevšednosti; jeho význam je spatřován ve společném prožitku založeném na vzájemné interakci, v jeho působení na formování citového vztahu k lokalitě vstupováním do jejích dějin jako součást vědomé lokální kulturní tradice (Kadeřábková 1991: 49).

Současný antropologický pohled na karnevalové slavnosti posunuje jejich zkoumání částečně do oblasti kulturálních studií (Karlová 2013), které si kladou otázku po smyslu a významu svátků. Opírají své úvahy o data kvalitativního výzkumu a nabízejí interpretaci jevu nejen v jeho lokálních konotacích, ale i v širších teoretických souvislostech. Zohledňuje se tu téma identity a integrace či otázky související s utvářením společenského statusu v rámci místního společenství (Stavělová 2005; 2006; 2008). Etnomuzikologicky zaměřené studie dále zkoumají roli hudby při tradování kulturní šablony masopustu (Kratochvíl - Tyllner 2007).

Mohlo by se tedy zdát, že jev je dostatečně prozkoumán z mnoha úhlů pohledu a nemá smysl se jím více zabývat. Předchozí práce se však zpravidla týkají místní tradice předmoderní doby, která je kontinuálně udržována, inovována nebo revitalizována. V našem případě jde však spíš o sledování procesu „vymýšlení tradice“ v místě, kde nelze navázat na žádnou předchozí podobu slavnosti. Je třeba si uvědomit, že v tomto př́ípadě studujeme kategorii novodobých festivit, vznikající v intencích postmoderní společnosti, která ve svém eklektickém přístupu k hodnotám minulým i současným konstruuje svou vlastní skutečnost. Při problematizaci tohoto jevu tu nenachází své místo pojem tradice jakožto přenos z generace na generaci, nejde ani o znovuoživení či reprezentaci nějaké místní tradice, ale jde tu naopak o vytváření nové situace ad hoc, která je výsledkem přediva sociálních a kulturních vazeb a potřeby jedince nalézt či ukotvit svůj prožitek identity v rámci širšího společenství. Jak přitom funguje či jaké uplatnění nalezne kulturní a kolektivní pamět, je otázka, která nás vybízí k přemýšlení. Jinými slovy, ptáme se, jak se tu propojuje nějaká tušená historická zkušenost i znalost s aktuálními potřebami vytváření novodobého kánonu umožňujícího současnou mezilidskou a sociální komunikaci. ${ }^{5}$ 
Proces vyjednávání o podobě dnešního masopustu na rozličných místech je sledován prostřednictvím dostatečného množství pořízených rozhovorů a na základě pozorování. Dalo by se předem shrnout, že klíčovými body vyjednávání o podobě masopustu jsou vesměs otázky:

- kudy povede průvod, kde začne a kde skončí, jaký je přitom vztah k místu,

- jak zapojit veřejnost - dospělé i děti (důraz je kladen na rodiny s dětmi) - aktivní spoluúčastí při výrobě masek a při jejich nošení v době konání slavnosti,

- jak podpořit interaktivitu pomocí hudby a tance - jaký repertoár zvolit, kdy a kde,

- tradiční masopustní gastronomie zprostředkující historickou vazbu.

Průvod, maska, hudba, tanec, jídlo a pití jsou bezesporu neodmyslitelné prvky masopustu všech dob, nás však bude zajímat, jak - s jakou intencí je dnes v patřičném socio-kulturním kontextu manipulováno s těmito projevy při konstruování kulturní šablony slavnosti, která se nazývá masopustem.

\section{Město jako jeviště aneb kudy půjde průvod 6}

Důležitým výchozím bodem našeho současného výzkumu je skutečnost, že se jedná o městskou slavnost. Prostor města a jeho pojetí z hlediska teorií urbanismu nabízí mnohé přístupy a podněty. Urbanizované lokality označuje sociolog Zygmunt Bauman za místo, kde se potkává vysoká míra lidských vztahů se strachem, jenž se zrodil z pocitu nejistoty a který hledá odbytiště a objekty, na něž by mohl svalit své břemeno - ačkoli tento stav nebyl pro tato místa příznačný odjakživa (Bauman 2008: 71). Důležitým rámcem zkoumání bude proto rozlišení soukromého a veřejného prostoru, přičemž veřejný prostor je vnímaný v první řadě jako fyzický a sociální fenomén. Veřejný prostor by měl být podle sociologa Wiliama Whytea (2001) místem, kde člověk může svůj individuální život sdílet s jinými lidmi a sám sebe prožívat jako součást většího celku - obce. Richard Sennett (1977) zase charakterizuje veřejný prostor jako místo pro formování společného na základě setkávání se s odlišnostmi. Veřejná sféra tu vystupuje jako protiklad sféry soukromé - tedy polarita, která činí město městem, souvisí zároveň s představami o demokracii a jejím formování. Tuto myšlenku uvedl v život německý sociolog a filozof Jürgen Habermas (1989), který v této souvislosti charakterizoval veřejný prostor jako místo, kde jde především o to konfrontovat se s druhými a s jejich odlišnostmi, či naopak podněcovat k hledání společného a sdíleného. Veřejný prostor klade zejména do souvislosti s rozvojem demokracie a potřebou debaty o věcech veřejných. 
Okolnost, kterou je dnes třeba mít na paměti, je nesamozřejmost veřejného prostoru v moderní zástavbě a v povaze dnešního života založeného na fyzické i mentální mobilitě člověka. Jde o skutečnost, že žijeme zároveň na několika místech, jsme průběžně vtahováni do virtuálního světa mimo fyzický prostor a vytváŕíme si tak nepevný, těkavý vztah k místu. Zatímco dříve člověk veřejný městský prostor navštěvovat musel, dnes je to věcí jeho volby či záliby. Veřejný prostor se proto mnohdy stává předmětem vyjednávání v souladu s novými formami jeho potencionálního využívání a naplňováním smyslem. Veřejný prostor je tedy třeba vnímat jako místo, kde je nutná živá komunikace lidí a jejich participace na dění v tomto prostoru, je to jeviště, kde jde o nalézání společné řeči (Kratochvíl 2013).

Slavení masopustu v uvedených městských částech Prahy či v jejím okolí se odehrává ve veřejném prostoru a logicky proto začíná úvahami o tom, kudy povede masopustní průvod. Jak ukazuje historická zkušenost, jsou průvody a procesí neodmyslitelnou součástí nejen fyzického, ale zejména sociálního veřejného prostoru, jsou jeho zviditelněním. Vyjednávání o trase masopustního průvodu je proto klíčovou otázkou, kterou řeší pořadatelé této slavnosti, a to nejen $z$ důvodu organizovaného záboru veřejného prostranství. Někde dokonce myšlenka vyhnout se úřední žádosti o tento zábor převládá a pořadatelé se snaží trasu koncipovat tak, aby zohlednila - kromě toho být viděn také další místní vazby a stala se spíš komunikačním prostorem. Intencionalita tohoto vyjednávání v souvislosti s tvorbou konceptu masopustu se tu potkává se spletitostí místních vazeb a možnostmi daného prostoru.

Pro masopust v Roztokách existuje dvojí řešení. Od samého začátku, kdy začala být slavnost koncipována v roce 1993 její vůdčí osobností, byla zvažována především možnost obchůzky po jednotlivých domech, od začátku však bylo jasné, že bude nutné postupovat selektivním způsobem.

Do Roztok jsem se pristěhovala s rodinou počátkem devadesátých let ${ }^{7}$ a hodlala zde pevněji zakotvit. Do té doby jsem jako herečka účinkující $v$ různých spolcích ponechávala zelenou svým botám $z$ toulavého telete až do doby, kdy jsem zatoužila po zapuštění kořenů. Roztoky mi padly do oka proto, že jsem tu pocítila možnost navázat hlubši mezilidské vztahy, masopustní tradice nabídla možnost kreativního zapojení dalších lidí. Něco podobného jsem zkoušela už ve svém predchozím bydlišti v Benešově u Prahy, moje výzvy se tu však nepotkaly s žádným ohlasem. Vzhledem k tomu, že jsem sama velice usilovala o to, abych se začala cítit v Roztokách opravdu doma,

7 Informátorka je absolventkou oboru výchovná dramatika na pražské DAMU, působí jako předsedkyně kulturního sdružení Roztoč v Roztokách u Prahy. Kromě toho, že iniciuje a organizuje mnohé kulturní aktivity, angažuje se také v místním komunálním životě a občanských aktivitách. Organizování masopustu, kde vystupuje jako emeritní královna, se stalo jednou z jejích promyšlených aktivit, kterou se snaží podpořit vztah k místu jak u sebe, tak u svých spoluobčanů. 
začala jsem přemýšlet o tom, jak vytvořit pro zdejši život nějaký společný rámec, který by umožňoval aktivní soužití místních lidí. Masopustní obchůzka se tak stala prostředkem $k$ seznamování... A dodnes to tak funguje. Každý rok vybereme $v$ určité části Roztok několik rodin, které se sem před nedávnem přistěhovaly a hodlají zde žít, a ty zahrneme do obchůzkové trasy. Jsou předem pripraveni na to, jak se vše odehraje a jaká jsou pravidla hry. Zatím nikdo neodmítnul, každý se snaží připravit štědré pohoštění, jak nejlépe dovede. ${ }^{8}$

Tato páteční obchůzka maškar s muzikou, tancem a pohoštěním před každým vybraným domem má skutečně soukromý charakter. Obchůzka je prováděna skupinou lidí, která se postupně vytvořila kolem kulturního sdružení Roztoč a pouličního divadelního a hudebního spolku Ledňák, časem se však přidali další aktéři, kteří zajištují hudební doprovod, ${ }^{9}$ nebo se podílejí na výrobě masek. Původně akce probíhala v sobotu, ale v okamžiku, kdy se začal počet účastníků nebo spíš přihlížejících rozrůstat, stalo se obtížné udržet tento charakter jakési domácí oslavy pro ty, kteří ji zároveň žijí, a došlo k jejímu utajenému přesunu na pátek a oddělení této obchůzky namířené dovnitř utvářející se komunity od okázalého sobotního průvodu masek (tj. za přítomnosti starosty a se zapojením široké veřejnosti). Intimita soukromého prostoru páteční obchůzky zůstala zachována, počet účastníků je jasně definován tím, kdo přijímá a kdo je přijímán, kdo tu je členem společenství a kdo je do něho rituálně začleňován.

Vedle toho předem medializovaný sobotní průvod, vedoucí od historicky významného místa obce - roztockého zámku - a pokračující přes stěžejní komerční náměstí dále na Holý vrch, nacházející se uprostřed mezi obcemi či městskými částmi Roztoky, Únětice a Suchdol, má odlišné poslání. Do maskovaného procesí, vedeného každoročně obměňovanou královnou masopustu (místní rarita), s několika druhy hudebního doprovodu se v rozmanitém přestrojení libovolně zapojují nejen místní obyvatelé Roztok, ale přijíždějí sem často a opakovaně také návštěvníci z jiných částí Prahy. Trasa je zabezpečená vyloučením dopravy, jako předvoj jsou předsunuté tzv. ometačky, které secvičeným tanečním pohybem vymetají cestu, kudy vede průvod, a viditelným způsobem tak vymezují jeho prostor a směrování. Kromě zahájení masopustu předáním jeho práva starostou do rukou hlavních aktérů na pódiu před roztockým zámkem, je další sugestivní podívanou defilé masek a jejich halasné představování na roztockém náměstí před nákupními centry, s cílem upoutat pozornost místních obyvatel vydávajících se za sobotními nákupy. Na chvíli je zcela ochromen běžný provoz tohoto prostoru a všichni jsou alespoň po tuto chvíli zaujati namísto nákupu touto výpravnou a hlučnou podívanou. Vše po

8 Rozhovor s Jitkou Tichou 26. 2. 2016.

9 V sobotním masopustním průvodu pravidelně účinkuje Blabuburo - skupina nadšenců provozující hudbu "afrických bubnů", kterou oživuji i jiné akce konající se ve veřejném prostoru. 
celou dobu svým vyvoláváním řídí a komentuje hlavní aktérka (zakladatelka zdejší slavnosti), emeritní královna masopustu. Průvod pak pokračuje na Holý vrch, kde je ukončen setkáním masopustních maškar - představitelů zmiňovaných sousedících obcí. Dojde ke komicky a groteskně pojatému bezzubému střetu těchto „masopustů“ - někdy jako hádání královen, jindy jako soupeření medvědů apod., a symbolickým usmířením všech zde průvod končí společným tancem - obrovským kolem složeným ze všech zúčastněných, kteří se chytnou za ruce a postupují v rytmu hrající kapely po jeho obvodu.

Večer pak následuje taneční zábava v blízkých Úněticích, které nabízejí vícero možností pro tradiční gastronomii, hudební a taneční vyžití v zařízeních místní sokolovny či vyhlášeného alternativního kulturního stánku Pražanům známého jako Kravín. Posílením místní dopravy o speciální Masobus se pak účastníci snadno dopraví do centra Prahy i v pozdních nočních hodinách.

Je to taková parádní show, zájem je opravdu veliký, lidé přijiždějí ze širokého okolí, někdy mám pocit, že už je to přiliš... Každopádně my si střežíme pro sebe pátek, ten je jenom náš a máme jej radši než tu sobotu, ta je víc pro ty ostatní, ne už tolik pro nás. ${ }^{10}$

Zatímco páteční obchůzka jasně vymezuje soukromý prostor města pro místní dialog a jeho navázání s novými přistěhovalci, poskytuje sobotní průvod mapu veřejného prostoru, který přesahuje rámec jedné obce vědomím sounáležitosti (přinejmenším kulturní) s širším prostorem komunálního soužití - Únětice například mají vhodný prostor pro společenský večer s hudbou a tancem, který Roztoky nemají, a bez tohoto vyvrcholení by roztocký masopust nebyl tím, čím je. A naopak bez kreativity, nápadů a iniciativy roztockých při organizování masopustu, by zase do Únětic nedorazila taková klientela za gastronomií a lokálním pivovarem.

Na rozdíl od zřetelné a ustálené koncepce obchůzky a průvodu roztockého masopustu je na pražské Letné otázka trasy masopustního průvodu stále ještě předmětem vyjednávání. Letenský masopust má za sebou zatím jen tři ročníky, přičemž první dva byly spíš připojením se hrstky lidí spřízněných s provozovatelkou a majitelkou galerie Skarabeus (v ulici Jana Zajíce přezdívané též jako Letenský Montmartre ${ }^{11}$ ) k pražskému masopustu, konanému na Staroměstském náměstí. Teprve letošní ročník začal být koncipován jako místní slavnost a přípravě ročníku začala být věnována zvláštní pozornost. Svou podporu má tato aktivita u místních radních - starosta v masce Bakcha nejenže předává s vtipným proslovem masopustní právo do rukou jeho aktérů, ale účastní se i jeho dalšího dění. Prvořadou se pochopitelně stala otázka,

10 Rozhovor s Jitkou Tichou 26. 2. 2016.

11 Letné se v období první republiky přezdívalo „Letenský Montmartre“ nejen díky sídlu Akademie výtvarných umění, ale také pro velké množství ateliérů, uměleckých hospůdek a kaváren. Přáním zakladatelky galerie Scarabeus bylo navázat na tohoto genia loci. 
kudy povede masopustní průvod. Zvažovaly se dvě možnosti: Vést průvod (1) od shromaždiště na Strossmayerově náměstí před kostelem sv. Antonína po stěžejní obchodní třídě Milady Horákové na Letenskou pláň, přes Scarabeus se zastávkou na pohoštění a krátkou produkci kejklírů a tanečníků, s ukončením průvodu v Národním zemědělském muzeu, které se organizačně také podílí na zabezpečení slavnosti zejména propůjčením prostor pro občerstvení a následný kulturní program. Nebo v př́ípadě velkého počtu lidí (2) neprocházet po hlavní frekventované třídě, ale ubírat se kolem Veletržního paláce přes Stromovku na Letenskou pláň. Nakonec zvítězila sice první možnost, ale hned následující dny po skončení slavnosti začaly vážné debaty o tom, nebude-li přece jen vhodnější z hlediska možnosti intenzivnějšího aktivního zapojení lidí možnost druhá. Letošní průvod totiž ukázal malé organické propojení s běžným provozem ulice, chyběli přihlížející, takže průvod prošel hlavní obchodní třídou téměř nepovšimnut. Doprava nemusela být odkloněna, protože průvod nepřesáhl počet, který by se vešel na chodník, a přestože policisté na koních, střežící bezpečnost při přecházení přes silnici, zajištovali svou př́ítomností patřičnou publicitu, procházel průvod vedený kapelou poměrně indiferentní ulicí, která nebyla nijak vtažena do hry a neměla možnost reagovat na jakékoli podněty. Zjevně tu scházela postava, která by byla nepřehlédnutelná, provokativní, vyvolávala rozruch a zájem okolí. Do budoucna se proto zvažuje způsob, jak by mohla trasa po obchodní třídě iniciovat zapojení drobných podnikatelů vlastnících zde obchody, uvažuje se však také o druhé možnosti, která počítá s podněty Národní galerie ve Veletržním paláci, která by mohla přispět kulturním programem, a zastavení by zde mohlo být koncipováno jako součást obchůzky s přijetím „domácími“. Následný postup přes Stromovku by zase mohl nabídnout zastavení na místech, kde by se nabídla příležitost a venkovní prostor pro tanec. Zapojením přihlížejících do tance lze pak předpokládat větší interaktivitu, zůstává však otázkou, jestli by se tak průvod nedostal mimo rádius čtvrti a neztratil kontakt $s$ jejím vnitřním pulzem.

Průvod břevnovského masopustu, který je pravidelně pořádán od roku 1994, má od začátku jasný cíl. Vzhledem k tomu, že je organizován Břevnovským sdružením živnostníků, vede jeho trasa jednoznačně po hlavní tepně Bělohorské ulice s hustým zastoupením obchodů místních drobných podnikatelů. ${ }^{12}$ Trasa není dlouhá, vede od historicky významného domu U Kaštanu po hotel Pyramida, kde je na prostranství před ním průvod zakončen vyhlášením a odměněním nejlepších masek, hudbou i tancem a příslušnou zabijačkovou gastronomií. V čele průvodu kráčí už po mnoho let s atributy svého řemesla řezník, který zastupuje jednu z nejvýznamnějších rodinných živností obnovenou v Břevnově krátce po roce 1989. Nezbytným prvkem tohoto průvodu je postava jakéhosi „plampače“, který za přispění ozvučovací techniky po

12 Sdružení živnostníků působí od roku 1992 a navazuje na předchozí existenci Spolku řemeslnickoživnostnického spojených a vůkolních obcí velkobřevnovských z roku 1880 a na činnost dalších cechovních korporací z roku 1922, např. na Podpůrný spolek řezníků a uzenářů pro Břevnov a okolí. 
celou dobu trvání průvodu upozorňuje na konkrétní firmy a jejich provozovny podél Bělohorské třídy a vše vtipně komentuje. Na několika místech také dojde k zastavení s malým pohoštěním (pekařství, řeznictví), maškary obléhají obchůdky a přimějí tak jejich provozovatele vyjít ven a pozdravit masopust. Průvod působí značně interaktivně, mnohé vtipné komentáře jsou adresné, lidé se průběžně přidávají, anebo vyhlížejí z oken. Automobilová doprava je sice ze silnice v obou směrech odkloněna, po kolejích však jezdí tramvaje a účastníci jsou průběžně policisty upozorňováni na dodržování vlastní bezpečnosti. Atmosféra je tu bezprostřední, řada lidí se vzájemně zdraví.

Podobnou náladu má také masopustní průvod v Buštěhradě, který má charakter obchůzky s muzikou v čele a se zastavením ve vybraných domech. Trasa je vedená členitě např́ič obcí se začátkem před muzeem místního rodáka spisovatele Oty Pavla a se zakončením v historicky nejstarší místní hospodě v původní zástavbě obce. Pohoštění u navštívených domů je bohaté, jako by se jejich obyvatelé navzájem trumfovali v představách o tradiční masopustní gastronomii.

\section{Stát se insiderem je v podstatě snadné}

Důležitým předpokladem participace v těchto slavnostech je vesměs maska, vnímaná jako důležitý krok, jak dát najevo svou př́slušnost ke každoročně utvářenému masopustnímu společenství. V Roztokách má dokonce každý návštěvník př́ležitost si v sobotu před průvodem zakoupit jednoduchou masku, nebo si ji vypůjčit od sdružení Roztoč s možností vrátit ji po skončení průvodu v Úněticích do speciálně přistaveného auta. Vedle toho je však pozoruhodná také vlastní kreativita zúčastněných, která rok od roku přináší pestřjejǐi podívanou. Těžištěm a jádrem roztockého sobotního průvodu však zůstávají už po řadu let vlastní specifické maškary, které se v průběhu let ustálily na postavy královny, klibny, Bakchuse, medvěda s medvědářem, čápa, prasete, Turka, báby s nůší, kozy, osla, koníků, ometaček a opic. K nim se přidávají masky kejklíre Vítka zvané Chudadla, zřejmě od chůd, na kterých se pohybují tyto nadrozměrné postavy s protáhlými pažemi. Jejich ovládání už vyžaduje patřičnou dovednost a privilegium nosit je a vodit náleží užšímu okruhu přímých aktérů, podobně jako rozpustilým „opicím“, které opakovaně každoročně vymýšlejí téměř akrobatické kousky lezením na stromy a budovy či poštuchováním účastníků průvodu. Roztocké maškary jsou už svým vzhledem natolik známé, že bývají identifikovány s tímto místem. Objevují se však také v břevnovském masopustu, který pomohli roztočtí rozběhnout a chodí tam za honoráŕ vypomáhat dodnes jako garance toho pravého masopustního ducha. Vedle některých vlastní kreativitou vytvořených masek se zde využívají zejména postavy tradičního vesnického masopustu - medvědář s medvědem, bába s nůší či rozverný kozel. 
Masce je velká péče věnována také při přípravě letenského masopustu. Jeho iniciátorka a organizátorka Kateřina Ebelová ${ }^{13}$ tak nezapře své výtvarné i divadelní vzdělání a profesi galeristky a nabízí různé příležitosti $\mathrm{k}$ přemýšlení o původu a významu masky přímo u zdroje. Ve své galerii Skarabeus uspořádala například letos v masopustním období výstavu masek současných tvůrců, které sama vyzvala $\mathrm{k}$ tvorbě na téma maska $\mathrm{v}$ našem životě. $\mathrm{V}$ týdnu před slavením masopustu na Letné uspořádala v galerii několik workshopů pro veřejnost s cílem poskytnout materiál a inspiraci pro vytvoření originální masky, která má vycházet především z vlastní představivosti.

Budu tam prípravená, i když třeba nikdo neprijide. Chtěla bych nabídnout lidem prostor pro přemýšlení o tom, co všechno může maska poskytnout, jak se naučit s ní pracovat a co vytěžit z možnosti vlastní proměny $v$ masku. Objevit svět pod maskou a vidět tak i sebe sama prostřednictvím masky, kterou si pro sebe vytvořim..$^{14}$

Břevnovský masopust naproti tomu přenechává iniciativu výroby masky na každém jednotlivci, snaží se však motivovat účastníky k tomuto kroku vyhlašováním a odměňováním vítězů v soutěži o nejlepší masku. Témata jsou zcela volná, kreativitě se meze nekladou, a tak se v masopustním průvodu této městské části, zaměřené díky zapojení místní mateřské školy na dětského účastníka, setkáváme s neobvyklým množstvím pohádkových bytostí, jaké si jen dnešní dítě vychované televizními příběhy dokáže za pomoci rodičů vymyslet. Je tu sestavena speciální skupina, která průběžně masky pozoruje a v závěru průvodu vyhodnotí nejlepší z nich. Ti jsou pak vyhlášeni a odměněni představitelem místní komunální politiky, v posledním ročníku místostarostkou městské části. Během průvodu jsou však zúčastnění „plampačem“ průběžně vybízeni k většímu zapojení do maskování - ročníky, kdy je účast masek hojná a pestrá, jsou hodnoceny pochvalně, zazněl však už i káravý tón.

Jako způsob participace a aktivního zapojení je převlek do masky také důležitou součástí buštěhradské masopustní obchůzky. Převlékají se do ní jak děti, tak dospělí všech generačních vrstev a její tvorba je tu výhradně ponechána vlastní fantazii každého jednotlivce či zájmových skupinek. svou početnou rodinou i bydlí, vřelý vztah. Její galerie i související Muzeum kávy s kavárnou se významným způsobem zapisuje do místního kulturního života, organizuje zde výstavy, autorská čtení, divadelní a taneční představení, ale také akce pro děti a jejich rodiče, systematicky přebudovává a rozšiřuje venkovní prostředí přilehlé zahrádky v multifunkční prostor, kde se setkávají rodiny s dětmi, herci malých divadelních forem, performeři divadla ulice, ale i osobnosti místní komunální politiky. Problematikou masky se zabývala ve své dizertační práci (Ebelová 2012). 


\section{Hudební společenství a jeho vlastní svět}

Kromě toho, že masopustní průvod musí být nejen vidět, ale i slyšet, je zapojení různých typů hudební produkce jedním z prvořadých úkolů, jak zajistit dobývání veřejného prostoru. $\mathrm{K}$ tomuto účelu bývá zajištěna účast různých typů kapel, které hrají v určitých fázích průvodu, při obchůzce či při taneční zábavě. Vytváří se tak specifický okruh laických hudebníků, kteří se opakovaně do karnevalově pojatých akcí zapojují a vytvářejí si tak v jejich rámci svůj vlastní hudební svět s osobitým repertoárem. ${ }^{15}$

Vztah hudby a místa, kde se hudba provozuje, si v průběhu posledních přibližně dvou desetiletí získává stále častější pozornost etnomuzikologů. Vazba mezi hudbou a konkrétní lokalitou byla samozřejmě registrována badateli mnohem dříve, ovšem teprve postupně se do hledáčku dostávají i možné varianty tohoto vztahu nad rámec konstatování, že daná píseň byla zapsána na určitém místě. Ukazuje se, že místo jako nejen fyzický - ale také mentální prostor - může hudební aktivity ovlivňovat, ale je jimi naopak také ovlivňováno, či dokonce formováno, jak píše Thomas Solomon: „V etnomuzikologii dnes běžně uznáváme, že provozování hudby může být činností, při níž je konstruována identita. Na první pohled již méně zjevné se může zdát, že při ní lze konstruovat též místo. Geografové a antropologové v poslední době zkoumají skutečnost, že místa nejsou pouhými předpřipravenými kulisami pro činnost, ale spíše jsou aktivně vytvářena a představována lidmi skrze společenské procesy.“ (Solomon 2006: 311) Na masopust v Roztokách u Prahy se např́klad v rámci takto vymezeného spektra a skrze konstruování hudebního repertoáru lze dívat z různých hledisek. Zajímá nás především jeho páteční, neveřejná část. Hlavní otázkou je, jak repertoár (tedy to, co se hraje) v kombinaci s provedením (tedy tím, jak se hraje) vytváří nový celek ze zdánlivě nesourodých prvků.

Hudební doprovod roztocké masopustní obchůzky není každý rok totožný a jeho podoba se neustále proměňuje. Následující text vychází především $\mathrm{z}$ výzkumu provedeného $\mathrm{v}$ lednu 2016 , z rozhovorů s aktéry a z materiálů, které poskytli. Pro dokreslení výzkumné situace je třeba doplnit, že šlo o zúčastněné pozorování. Účastníci obchůzky souhlasili s přítomností výzkumníka pouze pod podmínkou, že jako hudebník-klarinetista (se zkušenostmi s lidovou hudbou) bude při obchůzce také hrát. Tato perspektiva samozřejmě ovlivnila informace získané při pozorování, protože umožnila být sice během obchůzky v kontaktu především s hudebníky, ale zároveň neposkytla například možnost posoudit, jak hudbu vnímají tanečníci a další lidé pohybující se dál od muzikantů. Na druhou stranu ale bylo možné zblízka pozorovat komunikaci mezi muzikanty. V následující části půjde o zhuštěný popis událostí odehrávajících se v pátek přibližně od čtyř hodin odpoledne do půlnoci. 
Kapela hraje ve složení housle, dvě violy, basa, klarinet, zobcová flétna, akordeon a buben. Houslistu, violistu, violistku a flétnistu spojují zkušenosti z hraní ve folklorním souboru. Bubeník, violista, flétnista, basista a akordeonista jsou místní, ostatní žijí v jiných částech Prahy. K muzikantům se ještě připojuje jedna maska s trubkou, na kterou se podle vlastních slov učila hrát jen pár měsíců. Její hra je také velice jednoduchá a po nějakém čase končí. Jako součást průvodu masek se rovněž muzikanti před začátkem maskují a oblékají do kostýmů. Ve srovnání s ostatními maskami v průvodu se ovšem muzikanti zdobí jen málo, aby převleky nebránily hraní.

Muzika (bez bubeníka a naopak s druhou akordeonistkou, která na obchůzce nakonec nehrála) týden před obchůzkou společně zkoušela jádro repertoáru. Důležitou pomůcku představuje zpěvník obsahující jádro repertoáru pro obě složky obchůzky: koledování v domácnostech i přechody mezi nimi. Zpěvník vznikal řadu let, dříve než se v obchůzkách začali angažovat současní muzikanti. Podle informací muzikantů začal vznikat přibližně před deseti lety kompilací z různých zdrojů. Zpěvníček obsahující dvacet písní mají účastníci obchůzky $\mathrm{v}$ tištěné podobě, která ovšem není určena k veřejnému šiřrení. ${ }^{16}$ Zahrnuje písně různého druhu z různých regionů Čech, Moravy a Slovenska, vedle písní lidových bez uvedení autora v něm najdeme i píseň Podzim Petra Skoumala s textem Emanuela Frynty, k němuž je dopsána nová sloka s masopustní tematikou. Během obchůzky v roce 2016 tato píseň (stejně jako řada dalších ze zpěvníku) nezazněla. Naopak se zpívalo mnoho písní ve zpěvníku neuvedených.

Písničky nemají žádné speciální aranže, střídá se většinou sloka zpěvu s instrumentální přehrávkou. Výjimkou je píseň Jsom já synek z Orešan, kde housle hrají krátkou rytmickou figuru jako přechod před některými slokami, což bylo dohodnuto během zkoušky. Zpívají všichni muzikanti i většina masek. Muzika nemá oficiálního vedoucího nebo kapelníka. Rozhodnutí, co se bude hrát, v jakém tempu a tónině, vychází ze střídavé iniciativy jednotlivých muzikantů. Akordeonista je zároveň tak trochu dirigentem nebo režisérem průvodu a několikrát se rozhodne vlastním tělem zabránit v průjezdu autu a hraje před ním, dokud celý průvod neprojde, což někteří řidiči nesou hůře, jiní lépe. Rozložení rolí mezi nástroji odpovídá např́íklad moravské hudecké muzice, v níž housle hrají hlavní hlas, violy „kontrují“, tedy ve dvojhmatech vytvářejí harmonický a rytmický doprovod, flétna a klarinet střídavě hrají první a druhé hlasy. Akordeon se občas omezuje na harmonický doprovod, jindy také hraje melodii.

Po zahájení obchůzky jde kapela docela dlouho, než dorazí k první domácnosti, kde je třeba zastavit. Také přechody mezi dalšími zastávkami jsou poměrně dlouhé a s postupem času se prodlužují pauzy mezi písněmi. Velkou roli hraje počasí, které bylo tohoto večera velice chladné, což má vliv i na hudbu. Teplota několik stupňů pod bodem mrazu komplikuje ladění nástrojů, což se muzikanti

Publikaci určenou pro veřejnost organizátoři v době výzkumu zvažovali. 
ani nesnaží řešit. Některé nástroje se $\mathrm{v}$ důsledku toho mění z melodicko-harmonických na čistě rytmické. Violistka hraje v tlustých palčácích, což vylučuje možnost přesné hry na hmatníku, podobně tomu je u kontrabasu. Uvnitř klarinetu se asi po dvou hodinách začne tvořit ledová vrstva a nástroj jednoduše odmítá vydat tón. Během obchůzky jdou muzikanti někdy v jedné skupině, jindy se ale rozptýlí poměrně daleko od sebe, přičemž nepřestávají hrát. Jako zvukové pojidlo působí údery bubnu, které se nesou daleko a pomáhají rytmicky synchronizovat ostatní nástroje. Výjimkou je několik písní s proměnlivým taktem, při nichž se bubeník přestává orientovat a rytmus se rozpadá.

Při hraní před domy zaujímá muzika místo poblíž královny masopustu, aby byl dobře slyšet doprovod ke stálým obchůzkovým písním. Hraje se venku s výjimkou předposlední domácnosti, kdy je celý průvod pozván dovnitř na zahřátí. V obývacím pokoji se pak hraje a tančí asi třicet minut. Kromě výše zmíněných blokování aut dojde k intenzivnějšímu kontaktu s veřejností při přesunu k poslední domácnosti. Všichni účastníci průvodu i s muzikou se nacpou do autobusu městské hromadné dopravy řízeném lehce vylekaným, ale jinak vstřícným řidičem. Atmosféra přeplněného vozidla inspiruje všechny $\mathrm{k}$ intenzivnějšímu hraní i zpěvu. $\mathrm{V}$ poslední domácnosti se modus hudby mění. Na tomto místě se odehrává slavnostní zakončení obchůzky, které má podobu volné hudební a taneční zábavy. K muzice se přidává další houslista a cimbalistka, hrající na malý přenosný cimbál.

K masopustu ve všech jeho podobách patří jídlo a pití, především alkohol. Nejinak je tomu i při obchůzce v Roztokách, kdy kromě občerstvení připravovaného pro jednotlivá zastavení s sebou muzikanti nesou ještě malou láhev slivovice, která mezi nimi koluje. Vliv alkoholu ovšem během celého večera nezačne být u nikoho z hudebníků zjevný.

Písně, které si hudebníci vybrali pro masopustní obchůzku, pocházejí z různých lokalit v rámci České republiky. Jakou strategii můžeme hledat za jejich výběrem? A jak tento hybridní repertoár můžeme chápat v kontextu vzniku „nové tradice“?

Hudba hraje v průběhu masopustní obchůzky několik rolí: slouží jako doprovod k tanci a při přechodech mezi jednotlivými domácnostmi vytváří zvukový prostor rámující průvod a oddělující jej symbolicky od okolí. Repertoár je rozdělen na dvě skupiny. První část je úzce koordinována s tancem, proslovy a dalšími aktivitami, které se odehrávají při jednotlivých zastaveních. I v této části je možné pozorovat jistou volnost a proměnlivost, nicméně základní složky jsou vždy přítomny. Druhá část repertoáru pokrývá přechody skupiny koledníků mezi jednotlivými domy. Vzhledem k tomu, že koledníci byli pozváni pouze k několika rodinám v rámci Roztok, představovaly tyto přesuny podstatnou část večera. Během nich se netančilo a volba písní tak byla pouze na hudebnících.

Do první skupiny patří písně spojené s konkrétními tanečními projevy: melodii písně Šla Židovka do Slanýho, která doprovází společný tanec na ulici, 
můžeme najít v tzv. Rittersberkově sbírce (1825, nově vydal Markl 1987: 247), kde je jako místo jejího výskytu uvedeno Plzeňsko a Chrudimsko. Píseň Za ten len, za ten len, za ty konopičky vyšla například ve sbírce Lidové písně z Havlíčkobrodska (Thořová 2009: 183). Píseň se vymyká svou strukturou, kdy se zpívaná melodie stř́idá s výskoky všech zúčastněných. Před nimi muzika vytváŕí akustickou př́ípravu postupně zesilovaným tremolem na jednom akordu, po němž následuje výskok a opakování melodie. Tyto dvě písně představují nejstabilnější jádro repertoáru a mají své pevné místo. Další aktivity odehrávající se při jednotlivých zastaveních, především tanec s hostiteli, jsou již méně fixované a doprovázejí je různé melodie.

Při přechodech muzikanti vybírají z poměrně široké palety, některé písně jsou ale opakovány častěji než jiné. Mezi ně patří píseň Poslechněte lidé málo, co se v české zemi stalo (Plicka - Volf 1960), Zadělala na buchty (Markl 1987: 342), Pane bratříčku, dobrej den (Erben 1862), Já si tě má milá nevezmu (Erben 1862: 551), Když jsem já šel po mezi (Holas 1909: 126), Jsom já synek z Orešan (Sušil 1859: 544). Po hudební a textové stránce je těžké hledat mezi těmito písněmi nějakou spojitost. $V$ některých případech jde o písně s masopustní tematikou, jindy jde o písně obecně žertovné nebo pijácké. Centrální Šla Židovka do Slanýho textově sice s masopustem nijak nesouvisí, lze ji ale chápat jako odkaz na masku Žida, která je častou součástí masopustních průvodů.

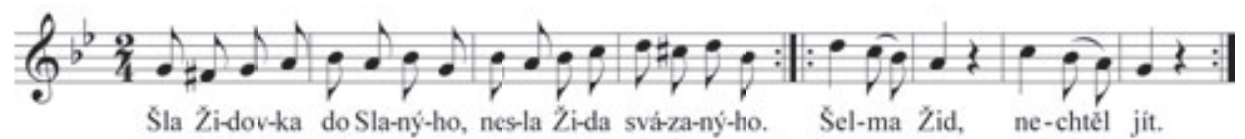

Totéž téma přináší píseň Byli jednou tři Židi (Thořová - Traxler - Vejvoda 2011: 228). Jindy byl výběr písní veden snahou zdůraznit charakter masopustu jako doby, kdy neplatí běžná pravidla a společenský řád ustupuje chaosu, jak jej charakterizoval Michail Bachtin (2007). V textech se tedy objevuje nonsensový humor, opilství a obžerství. Zvláštní oblibě se během obchůzky těší popěvek, který muzikanti zpívají s teatrálně přehnaným „opileckým výrazem“ a odpovídajícím nepravidelným rytmem:

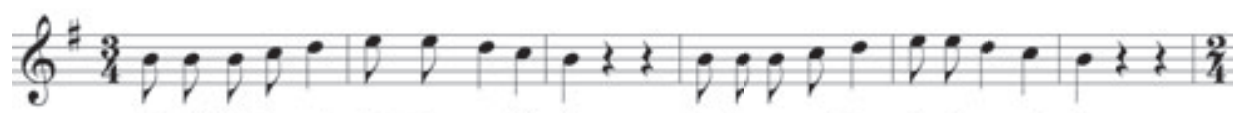

Až pr̂̀i-jdu do-mũ, vše-chno roz-bi- ju,

dve-f̌e vy-vrá-tím, že-ně na-mlá-tím.

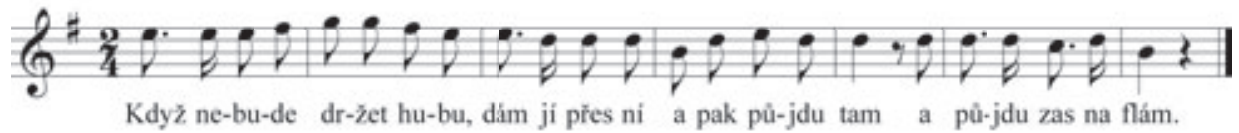

Když ne-bu-de dr-žet hu-bu, dám ji pr̃es ni a pak pû-jdu tam a pû-jdu zas na flám.

(srv. Thořová - Traxler - Vejvoda 2011: 223) 
Ač je možné dohledat, kde byly jednotlivé písně sebrány, nepodařilo se jednoznačně určit, jakými cestami se dostaly do masopustního repertoáru. Ǩadu z nich pravděpodobně muzikanti znají ze svého působení ve folklorním souboru, jiné jsou zřejmě výsledkem cíleného pátrání ve vydaných sbírkách, ovšem otázku původu hudebníci nepovažují za důležitou. To se potvrdilo i během zmíněné přípravné zkoušky, kdy každý z hudebníků zpaměti nadhazoval melodie, o které by bylo možné repertoár rozšírit. Původ písně v tu chvíli nikoho nezajímal.

\section{Tradice versus fúze}

V oblasti tradičně chápané evropské lidové kultury jsou písně vždy chápány jako útvary úzce spojené s místem svého původu. Identifikace písně jako jednotky pocházející z konkrétní lokality představovala v 19. i 20. století důležitou součást sběratelské, badatelské a také vydavatelské činnosti. Zároveň sběratelé začali velmi záhy brát v úvahu skutečnost, že vazba na konkrétní místo je jen omezená a že naopak lze písně považovat za „nejneúnavnější turisty na zemi“ (Tappert 1890: 5). Regionální čistota je tedy do jisté míry iluzorní, protože repertoár i styl jednotlivých oblastí byl vždy proměnlivý a jednotlivé regiony se navzájem ovlivňovaly. Nicméně jde o kvalitu, jež byla vždy v rámci folklorního hnutí často zdůrazňována. Při pohledu na existující sbírky lidových písní z území České republiky je zjevné, že různé regiony se těšily větší pozornosti sběratelů a tedy je s nimi spojen rozsáhlejší repertoár než s jinými. Některé oblasti zůstaly sběratelskou činností téměř nedotčeny.

Roztoky u Prahy patří právě k místům sběratelstvím v podstatě nedotčeným. ${ }^{17}$ Při hledání repertoáru k nově vznikající lokální slavnosti se tedy její aktéři rozhodli jít cestou hybridizace, kdy propojili vzájemně nesouvisející materiál do nového celku. Jednotícím prvkem se - vedle některých témat zmiňovaných výše - stal styl hry. Hybridizace může mít nejrůznější podoby včetně záměrného spojování výrazně odlišných hudebních poloh a stylů, jak to lze slyšet u skupin spojujících lidové písně s rockovou či elektronickou instrumentací. Během veřejného průvodu městem následující den je do hudební produkce zapojeno několik těles na první pohled i poslech odlišných a ona stylová hybridita je zdůrazňována jako důležitá kvalita. ${ }^{18}$ Při páteční obchůzce je ovšem hudební různorodost na první poslech přetavena do homogenního tvaru.

17 To platí i obecně o lidových písních z Prahy a okolí, kde teprve v posledních letech dochází k zaplňování mezery díky postupnému vydávání sbírky Františka Homolky z počátku 20. století (Thořová - Traxler - Vejvoda 2011; 2013). Dosud vydané svazky obsahují po jedné písni z Únětic a Šárky, tedy lokalit sousedících s Roztokami, ovšem ani jedna z těchto písní v roztockém masopustním repertoáru není. Sobotní obchůzka zahrnuje ansámbl bicích nástrojů hrajících latinskoamerické rytmy, dechovou kapelu i sólového houslistu, na večerní zábavě hrál v roce 2016 bigband nebo skupina věnující se židovské hudbě. 
Většina hudebníků, kteří se podíleli na této obchůzce, má dlouholetou zkušenost s působením ve folklorním souboru a ocitají se tak v poněkud rozporuplné situaci. Soubor, v němž hrají, je zaměřen na jeden region jižní Moravy a stejně jako řada podobných těles usiluje většinou o jistou regionální věrnost. Ta se projevuje ve výběru písní i ve způsobu jejich provedení. Důraz na lokální či regionální identitu hudby můžeme chápat jako snahu o boj proti kulturní homogenizaci. Tato obava není ničím novým a není ani omezena na české a moravské folklorní hnutí (viz např. Nettl 1983: 345). Zároveň ovšem hrozí jak proměnou tradiční hudby v muzejní exponát, tak rovněž zastírá skutečnost, že žádná důsledně fixovaná podoba vlastně neexistovala, a tak se vytváří její falešný obraz (Kratochvíl 2013). Jistá míra unifikace je doložitelná při pohledu do historických pramenů, a při specifických př́ležitostech, jako jsou výroční obyčeje, byla vždy určitá míra omezení výběru nápadnější. Příkladem může být nedávno zkoumaná masopustní obchůzka v Dobrkovské Lhotce (Kratochvíl Tyllner 2007), která trvá celý den, a při jejím doprovodu, obstarávaném akordeonem, trubkou a baskřídlovkou, se důsledně střídají jen tři písně.

Autenticita je u tradiční hudby většinou chápána mimo jiné jako respektování původní lokality repertoáru a přístup hudebníků z Roztok je s tímto pojmem ve zdánlivém rozporu. Zde je ovšem třeba připustit, že existují různá chápání autenticity. Na dneším masopustu v Roztokách se nacházíme v odlišné situaci než sběratelé jako Erben či Sušil v 19. století, kteří ještě mohli vnímat písně jako pevně svázané s lokalitou zápisu. O více než sto let později je díky vývoji technologií, přesunu obyvatel z venkova do měst a dalším faktorům vazba písní na místa, kde byly zaznamenány, výrazně slabší. Také samotný pojem autenticity v hudbě byl mnohokrát zproblematizován a předefinován (viz např. Connel - Gibson 2003: 19-45). Sepětí hudby, místa a komunity lidí je tak vždy znovu definováno konkrétním prováděním. Místo se v takovém př́ipadě stává pojítkem nejen fyzickým (protože ne všichni účastníci v Roztokách žijí), ale také symbolickým či mentálním. Hudba se tak stává silou, která místu definovanému fyzicky či geograficky dodává další rozměr. Podobně jako v Roztokách je hudební doprovod organizován místními hudebníky - rovněž zčásti se zkušenostmi ze souborového hnutí - například v Buštěhradě, další lokalitě nepříliš zachycené ve sbírkách lidových písní. Naproti tomu např́íklad masopust na Žižkově využívá profesionální hudebníky bez konkrétního vztahu k místu.

\section{Místo pro tanec}

Vyjednávání o podobě tance je také jednou z klíčových otázek při vytváření podoby slavení masopustu ve všech zmiňovaných oblastech. Za vyvrcholení slavení masopustu je ve všech uvedených případech považována společná zábava s hudbou, tancem a tombolou, tedy chvíle setkání, kdy se lidé dostávají k sobě trochu blíž. Ani zde však tento proces neprobíhá stejně. Základní 
otázkou je, co tančit. Dobře se z této otázky vykroutili pořadatelé břevnovského masopustu. Už řadu let je na taneční zábavu zváno v rámci průvodu do hotelu Pyramida, kde probíhá jako maškarní bál. Téma masek (např. hudba, jídlo, od pohádky k filmu ad.) jako jakýsi dress code je tu každoročně obměňováno. Je už skoro nemožné přijít na tento společenský večer civilně, aniž by si člověk nenasadil alespoň škrabošku. Bez tohoto převleku se tu za chvíli začne cítit nepatřičně a nápadně, jako někdo, kdo sem nepatří. Zdá se, že účastníci se mezi sebou často znají jako členové spolku místních živnostníků, jakákoli nová tvář přikrášlená maskou je však přijata jako samozřejmost. K tanci hraje najatá taneční kapela zběhlá v hraní rozmanitého repertoáru swingových, foxtrotových, bluesových, polkových či valčíkových melodií, včetně oblíbených diskotékových hitů. Tance se s dávkou bezprostřednosti účastní většina přítomných bez rozdílu věku - i když foxtroty a polky nejdou každému, tady na tom nezáleží, maska přeci dovoluje všechno. A tak se taneční parket plní spontánními kreacemi na jakoukoli hudbu, stejně tak jako pečlivě vykrouženými otočkami noblesního waltzu.

Podobný charakter má i zábava v únětické sokolovně po skončení roztockého masopustního průvodu. Potkávají se tu „skalní“ aktéři v tzv. dolnopovltavském kroji, který si vymyslela a rozmanitě sama zhotovila jejich ženská část, s kýmkoli, kdo má chut se tu zdržet po absolvování průvodu byt' v turistickém oblečení. Taneční parket je stále plný. K tanci hraje zkušená taneční kapela usazená na pódiu a hrající bezbřehý repertoár tanečních melodií. Po parketě krouží v rytmu tanga dvojice v rafinovaných figurách pražských milong, vedle nich se klátí s batohem na zádech a se sklenicí piva v ruce osamělý mladík, o kus dál skupinka rozdováděných děvčat předvádí improvizovanou kreaci na neznámé téma, mnozí se pohupují na místě otočeni směrem k pódiu, odkud se line hudba, přitom popíjejí a cítí se stejně uvolněně jako na rockovém koncertě. Tanec tu pro každého znamená to, co právě dovede a co je schopen propojit s atmosférou parketu.

Jiná je však situace při roztocké páteční obchůzce. Tanec tu má jiné poslání, než jen navodit pocit sounáležitosti a sdílení uvolněné atmosféry. Důležité je tu zapojit do společného díla ty „neznámé“, kteří se sem přistěhovali. Společný tanec se tu tak stává sdílenou hodnotou, kterou je třeba specifikovat, vyčlenit z běžného slovníku a učinit z ní rituální jazyk, který si osvojí ti, kteří mu mají rozumět. K tomu je sestaven specifický repertoár čistě masopustních písní a tanců, provozovaných pouze v tomto kontextu. Byly vyhledány ve sbírkách lidových písní a tanců a uplatněny s konkrétním záměrem zapojit do něj cílovou skupinu aktérů, sestávající z obchůzkářů a přistěhovalých obyvatel. Před každým z navštívených domů se tančí židovka - velmi jednoduchý řadový tanec s postupným zapojováním dvojic do společného tance. Jednoduché běhové kroky nevyžadují žádnou zvláštní taneční znalost, jde jen o to zavčas pochopit, kdy se má dvojice uklonit čelem k sobě a kdy zády. Tato jednoduchá forma umožňuje rychlé zapojení do tance všech 
zúčastněných. Potom už se hrají náročnější kousky - například mateník medvěd (Já si tě, má milá, nevezmu, že ty jsi podobná medvědu). Nikdo z účastníků nepozná, že se v tanci střídá lichodobý a sudodobý takt a přesto tančí v páru s koledníky, kteří je svérázným způsobem berou do tance. Nikdo se nebrání, tančit s maškarou přeci znamená, že jde o legraci a ne o tanec. Společný tanec obchůzkářů s „hospodáři“ je zakončen tzv. vyskakováním na len (Za ten len, za ten len, za ty konopičky), všichni na patřičném místě textu písně společně vyskočí do výšky, tanec se v tuto chvíli mísí s hlasem královny, která za všechny přeje obyvatelům domu mnoho lásky, dětí a spokojenosti v novém bydlišti. Původně lidový tanec s prvky prosperitní magie (jak vysoko se při tanci vyskočí, tak vysoko naroste len) má být i dnes vyslovením přání úspěchu a hojnosti. Tento ceremoniál „vítání nových spoluobčanů“ se pak opakuje před každým vytipovaným domem.

Tance jsem vybírala se zřetelem $k$ tomu, aby se nejen svým obsahem vázaly k masopustu jako takovému, ale aby byly zároveň jednoduché a lidé se mohli do nich rychle zapojit. To zapojení do tance je jako príietí mezi nás. Tance je však stále málo, lidi nevědí, co tančit, proto jsem se rozhodla začít pravidelně pořádat Roztocké dvorky s výukou tance - pokaždé někde jinde $v$ soukromí, podle toho, kdo bude ochoten na svém dvorku tuto odpolední akci uspořádat. Budeme sem zvát lektory, kteří budou vyučovat lidové tance různých oblastí, aby byli lidé lépe vybaveni a mohli si zatančit mnohem širší repertoár než dosud. ${ }^{19}$

V Buštěhradě se nabízí odlišný obrázek taneční zábavy pořádané ve stylové a designově zajímavě pojaté vinárně. Výjimečný zážitek slibuje podle plakátku účinkování cimbálové muziky Buštěhradištan Oty Pavlici. Repertoár moravských lidových písní a tanců rozehrává krev v žilách, taneční parket však zeje prázdnotou. Teprve později se jeden pár pokouší o vlastní verzi čardáše, který se mu však brzy vymkne z rukou (nohou) a pár se znaveně odklátí ke stolu. Uvolněnou náladu podpořilo nakonec vyhlašování nápadité tomboly s recyklovanými výhrami, které pobavily osazenstvo sálu. Poté se zábava začala točit více kolem jednotlivých stolů a jejich konzumace. Lidé se tu však vzájemně dobře znají, takže ke sbližování tanec zas tolik nepotřebují. Zábava se však poměrně brzy chýlí ke konci a všichni se pomalu rozcházejí.

A vy jste kdo? - zeptala se mě paní od vedlejšího stolu. Budete o nás psát do novin? -pokračovala s pohledem na mou fotografickou 
výbavu. Kdepak, uklidňovala jsem ji, aby si nemyslela, že jsem nějaký paparazzi, který je bude vláčet bulvárním tiskem, já jsem jenom etnoložka a zajímá mne masopust... Aha, pokračovala zjevně potěšena mým zájmem, tak to byste nám mohla přispět fotografii do našich novin, víte, nám letos nedorazila fotografka a my ten náš masopust chceme mít každý rok zachycený. Záběry z taneční zábavy nám většinou chybí - a prritom se tu lidi tak hezky baví. Snažíme se u nás o různé kulturní aktivity, abychom se cítili jako mezi svými a aby se sem lidi rádi vraceli a cítili se tu doma. Masopust pořádáme od roku 2005 a stále je co vylepšovat... ${ }^{20}$

Velkým oříškem, jak využít možnosti tance pro aktivní zapojení lidí do slavnosti, se stala tato otázka pro pořadatele masopustu na Letné. Jeho spektakulárnost zajistilo tancem letos taneční oddělení místní Základní umělecké školy. Děti předvedly na náměstí před kostelem stylizovanou formu masopustního reje na hudbu muziky Hradištan, na zakončení slavnosti pak byl připraven v Národním zemědělském muzeu tzv. balfolk s výukou tance. ${ }^{21} \mathrm{Za}$ doprovodu balkánské folklorní hudby tu proběhla spontánní výuka těžko definovatelného tanečního stylu s cílem zapojit zúčastněné. Tento bod programu se však dostal ke slovu až v pozdní hodinu a týkal se už jen malé hrstky lidí. Pořadatelé si proto lámou hlavu, jak vyřešit otázku taneční zábavy a jaké pro ni získat prostory i čas v příštích ročnících. Tanec je vnímán jako důležitý prostředek interakce, bez něj nebude masopust tím, čím má být. Jde jen o to, co tančit, aby to bylo lidem blízké, jak lidi k tanci vůbec dovést, v které části slavnosti to bude nejvíc vhodné a kde pro to bude patřičné prostředí. Některé místní sály s dostatečnou kapacitou často nepřitahují zájemce k návštěvě, a naopak tam, kam místní chodí rádi, není dostatečný prostor pro tanec. Uvažuje se také o postavě „animátora“, který by i během průvodu dokázal nenásilným způsoben navodit atmosféru k tanci a rychle do něj zaškolit.

Poslední dva příklady ukazují na nedostatek taneční kompetence, na základě které je možné využít performativní prvky tance, které napomáhají rozvinutí intenzivní místní komunikace. Ta se pak děje na úrovni symbolických sdělení, kterými je na člověka přenášeno sdílení společných emocí. Pořadatelé místních slavností si tyto možnosti tance uvědomují, a hledají proto způsob, jak situaci řešit ve světě roztřrištěných zájmů a odlišných kulturních zkušeností.

20 Z terénního deníku 15. 2. 2016.

21 Balfolk Ize charakterizovat podle reklamních nabídek jako World music přenesenou na taneční parket, nebo jako všechny tance světa. Jde o druh tanečních zábav, kdy se tančí na hudbu jakéhokoli lidového tance (např. mazurka, polka, bourrées, bretaňské tance ad.) rozmáhajících se od 70. let v Evropě, zejména v Německu, Holandsku a ve Francii. 


\section{Mezi kulturní pamětí, imaginací a kolektivní identitou pomysIného společenství}

To, co spojuje všechny uvedené případy slavení masopustu je skutečnost, že tu jde o hledání výrazu pro dnešní potřebu společenského soužití. Dochází přitom k využívání prvků rurálních forem masopustu předmoderní doby ke konstruování kulturní šablony dnešních slavností. Vybírají se však pouze takové prvky, které rezonují s představami o hodnotách, idejích, kreativitě, fantazii či o politických a občanských postojích, které mohou být kolektivně sdíleny. V souladu s těmito imaginacemi jde ruku v ruce snaha vytvořit jakousi společnou kanonizovanou podobu vzájemného bytí, která by mohla být pravidelně opakována a naplňována dalšími obsahy. Nabízí se tu otázka, proč právě masopust. Významným momentem je - jeho historicky neoddiskutovatelné - zařazení v čase i přesto, že termín konání slavnosti bývá dnes často v jednotlivých lokalitách podle místních potřeb (např. z důvodu jarních prázdnin) posunován v rozmezí dvou až tří týdnů a Popeleční stř̌eda nemusí být vždy definitivním ukončením masopustu. To ale nemění nic na skutečnosti, že slavení masopustu je vesměs spojováno s obdobím kolem původního termínu, v celoročním cyklu má své pevné místo a stává se tu jednou z mála jistot, které se nemění. Pádným důvodem k dnešnímu slavení masopustu tu bezesporu může být i jakási historická zkušenost s jeho konceptualitou, která dovoluje manipulovat s významy v duchu společných intencí.

Významnou okolností může být i to, že proces reprezentace vesnického masopustu v městském prostředí může probíhat mnoha různými způsoby a na různých úrovních kulturní paměti, která se tu snadno stává kolektivní někdo se s masopustem setkal kdysi dávno na venkově u své babičky, někdo jej zažil v sousední čtvrti, viděl v televizi nebo o něm někde četl atd. Kolektivní pamět se podle Maurice Halbwachse (1992: 54) formuje vědomým vztahem k minulosti, vzpomínka se utváŕí z obrazů nepřítomných věcí. Mozek aktualizuje tyto věci v podobě obrazů a přizpůsobuje je specifickým situacím. Pamět́ je však zároveň sociálně podmíněná a do procesu vzpomínání se dostává pouze to, co má vztah k prrítomnosti. Opakováním vzpomínek vzniká tradice, kterou Halbwachs definuje jako přetvoření vzpomínek v určitou zvyklost. Jan Assmann (2001: 36-38) k tomu dodává, že kolektivní pamět řídí jednání a vzpomínání v rámci interakce společnosti a do jisté míry tyto procesy ulehčuje tím, že představuje kolektivně sdílené vzory. Podstatné je, že kolektivní pamět pracuje pouze s úzkým výběrem historických skutečností, které přizpůsobuje svým představám a je užívána k různým cílům. V kulturní paměti je minulost přetvořena do symbolických figur a je zpřítomněna v obřadech, které mají sváteční ráz, přičemž figury vzpomínek zakládají na skupinovou identitu. Pro kolektivní pamět je důležité sociální prostředí - jedinec se zde 
ztotožňuje s událostmi, osobnostmi apod., jejich trvání je však omezené na dobu trvání této skupiny. ${ }^{22}$

V neposlední řadě se nabízí také zamyšlení nad tím, ze kterých prvků se dnešní pražské masopusty konstituují a které tam ve srovnání s jeho historickými formami scházejí. Překvapivým zjištěním je na první pohled zřejmá absence konfliktu, legitimizovaného násilí a satiry. Nabízí se srovnání se současným výzkumem basilejského Fasnachtu, který je největším karnevalem Švýcarska a zároveň „gejzírem tvořivosti, satiry a svobody“ (Cieslarová 2011: 13). Vystavěný na historicky doložené místní tradici je zároveň fenoménem současné společnosti vyrovnávající se kreativním způsobem skrze umělecké ztvárnění s aktuálními místními i obecně palčivými tématy, která jsou takto beztrestně, naplno a zveličeně zobrazena a vyjádřena (Meier - Christ 1968). Je projevem vyspělé demokratické společnosti se silným vědomím kolektivní identity, která je informována o dění kolem sebe a poučeně reaguje s přímočarou razantností, kterou poskytuje svoboda masky a liminalita karnevalových dní. Satira a pamflety jsou tu dlouho dopředu pečlivě připravovanými výstupy, které nenechají nepovšimnuto nic, co se děje kolem. Jako nástroj společenského dialogu zde funguje tento svátek snad od počátku své existence. Na rozdíl od toho jsou pražské masopusty charakteristické převládající snahou po koncensu, prostoru liminality je využíváno spíš k alternativním myšlenkám. Možnost př́tomnosti konfliktu a tzv. rituálů násilí (Creed 2004: 56-70) jako by snad vyvolávala obavu z jejich proměny ve skutečnost (Le Roy Ladurie 2001). Jen velmi nesměle se letos poprvé objevily v břevnovském průvodu nápisy s povzdechem: „Šašků je mnoho, klaunů málo“. Je tedy možné, že postupně se i satirické aspekty stanou aktuálními a bude nalezen způsob, jak s nimi manipulovat a využívat jich jako jazyka veřejného prostoru.

I když toto „vymýšlení tradice“ do značné míry koresponduje s charakteristikou „invented tradition“ (Hobsbawm - Ranger 1983), nabízí se otázka, zda skutečně půjde o tradici. Základní atribut tradice, tedy přenos z generace na generaci, vyžaduje vždy po několik generací pevné spojení s místem pro zaručení kontinuity přenosu. Přestože do současných slavností jsou důsledně zapojovány děti a někdy lze nabýt dojmu, že se to koná zejména pro ně a jejich rodiče, nelze $\mathrm{v}$ dnešním mobilním světě očekávat, že $\mathrm{v}$ tomto prostředí zůstanou, až dospějí. Konstruováním kulturní šablony však vzniká možnost jejího pravidelného každoročního opakování v daném čase na konkrétním místě, a tato repetitivnost pak vytváŕí povědomí rituálu, který vždy znovu nastartuje pocit jakési kolektivní identity. Tento konstrukt se zároveň stává mentálním vlastnictvím nebo jakýmsi symbolickým kapitálem (Bourdieux 1993) takto vymezeného společenství, které na jeho pravidelné obnově participuje a identifikuje se s ním. Vzniklé společenství je však zároveň pomyslné či spíše, s přihlédnutím k intencionalitě konání vůdčích osobností, myšlené. Vzniká 
a existuje především v představách lidí, zatímco jeho provázanost s místem je často nejistá a proměnlivá (Anderson 1991; Boyes 1993). Tento proces lze tedy spíš charakterizovat jako vymýšlení či utváření společenství, které může existovat právě tak dlouho a často, jak o to budou jeho aktuální aktéři usilovat, a pro které se to stane alternativou, jak dosáhnout pokaždé vědomí kolektivní identity v bezbřehém prostoru urbanizovaných celků.

\section{Září 2016}

\section{Prameny a literatura}

Anderson, Benedict. 1991. Immagined Communities: Reflection on the Origin and Spread of Nationalism. New York: Verso.

Assmann, Jan. 2001. Kultura a pamět. Písmo, vzpomínka a politická identita $v$ rozvinutých kulturách starověku. Praha: Prostor.

Bachtin, Michail. 2007. Francois Rabelais a lidová kultura středověku a renesance. Praha: Argo.

Bauman, Zygmunt. 2008. Tekuté časy. Praha: Academia.

Borovský, Tomáš. 2014. Svátky a slavnosti středověkého města. In: Nodl, Martin - Šmahel, František (eds.): Slavnosti, ceremonie a rituály v pozdním středověku. Praha: Argo.

Bourdieux, Pierre. 1993. The Field of Cultural Production. Cambridge: Polity Press.

Boyes, Georgina. 1993. The Imagined Village. Culture, Ideology and the English Folk Revival. Manchester and New York: Manchester University Press.

Buckland, Theresa. 1995. Embodying the Past in the Present: Dance and Ritual. In: Dabrowska, Grazyna - Bielawski, Ludvik (eds.): Dance, Ritual and Music. 18th Symposium of the ICTM Study Group on Ethnochoreology, Skierniewice, 1994, Poland. Warsaw: Polish Society for Ethnomusicology, Institute of Art, Polish Academy of Sciences.

Buckland, Theresa. 2001. Dance, Authenticity and Cultural Memory: The Politics of Embodiment. In: Kaeppler, Adrienne L. - Christensen, Dieter - Wild, Stephen (eds.): Yearbook for Traditional Music 33: 1-16.
Burke, Peter. 2005. Lidová kultura v raně novověké Evropě. Praha: Argo.

Cieslarová, Olga V. 2011. Fasnacht. V Basileji karneval? Praha: Brkola, s. r. o.

Cohen, Anthony P. 1985. The Symbolic Construction of Community. London: Routledge.

Connel, John - Gibson, Chris. 2003. Sound Tracks: Popular Music Identity and Place. London: Routledge.

Creed, Gerald W. 2004. Constituted through Conflict: Images of Community (and nation) in Bulgarian Rural Ritual. American Anthropologist 106: 56-70.

Dülmen, Richard van. 2006. Kultura a každodenní život v raném novověku (16.-18. století). Díl II. Praha: Argo.

Ebelová, Kateřina. 2012. Maska v proměnách času a kultur. Praha: Grada.

Erben, Karel Jaromír. 1862: Nápěvy prostonárodních písní českých. Praha: Nákladem vydavatelovým.

Frolec, Václav - Tomeš, Josef (eds.). 1979. Masopustní tradice. Lidová kultura a současnost sv. 5 . Brno: Blok.

Frolec, Václav. 1982. Lidová obyčejová tradice a obřadní kultura. Terminologické otázky. Národopisné aktuality 19: 253-272.

Frolec, Václav. 1984. Prostá krása. Deset kapitol o lidové kultuře v Čechách a na Moravě. Praha: Vyšehrad.

Gluckman, Max. 1963. Order and Rebellion in Tribal Africa. Collective essays with authobiographical introduction. London: Cohen and West.

Habermas, Jürgen. 1989. The Structural Transformation of the Public 
Sphere. An Inquiry into a Category of Bourgeois Society. Cambridge, MA: MIT Press. [German 1962]

Halbwachs, Maurice. 1992. On Collective Memory (Heritage of Sociology). Chicago; London: University of Chicago Press.

Heers, Jacques. 2006. Svátky bláznů a karnevaly. Praha: Argo.

Hlubuček, Jan. 1953. Doudlebský rok. II. Zvyky masopustní. Trhové Sviny: Doudlebský archiv národopisný: nepublikovaný materiál, fond EÚ AV ČR, v. v. i.

Hobsbawm, Eric - Ranger, Terence (eds.). 1983. The invention of Tradition. Cambridge: Cambridge University Press.

Holas, Čeněk. 1908-1910: České národní písně a tance. Díl I-VI. Praha: B. Kočí.

Jakubíková, Kornélia. 1994. Sprievod ako etnologický problém. In: Tarcalová, Ludmila (ed.): Slavnostní průvody. Uherské Hradiště: Slovácké muzeum: 17-22.

Jurková, Zuzana a kol. 2014: Pražské hudební světy. Praha: Karolinum.

Kadeřábková, Jaroslava. 1991. Slavení masopustu a vesnická lokální společnost. (Některé výsledky současného srovnávacího výzkumu v ČR a SRN). In: Jančář, Josef (ed.): Slavnosti v moderní společnosti. Sborník příspěvků z XI. Strážnického sympozia, 11.-12. 9. 1990. Strážnice: Ústav lidové kultury: 44-50. Karlová, Jana. 2013. Slavnosti a rituály jako zpráva o obrazu světa. Červený Kostelec: Pavel Mervart.

Kratochvíl. Petr. 2013. Architektura a veřejný prostor. Praha: České učení technické.

Kratochvíl, Matěj. 2013. Už zase zachraňují národní tradice. [201610-10] Dostupné z: http://www. hisvoice.cz/cz/articles/detail/1600.

Kratochvíl, Matěj - Tyllner, Lubomír. 2007. Masopustní koleda na Doudlebsku. Praha: Etnologický ústav AV ČR.

Le Roy Ladurie, Emmanuel. 2001. Masopust v Romansu. Od Hromnic po Popeleční středu 1579-1580. Le Carnaval de Romans. De la Chandeleur au mercredi des Cendres 1579-1580. Praha: Argo.

Markl, Jaroslav. 1987. Nejstarší sbírky českých lidových písní. Praha: Editio Supraphon.
Meier, Eugen A. - Crist, Robert B. 1968. Fasnacht in Basel. Basel: Pharos - Verlag.

Muir, Edward. 2005. Ritual in Early Modern Europe. Second edition. Cambridge: Cambridge University Press.

Nettl, Bruno. 1983. The Study of Ethnomusicology. Twenty-nine Issue and Concepts. Chicago: University of Illinois Press.

Nodl, Martin - Šmahel, František (eds.). 2014. Slavnosti, ceremonie a rituály v pozdním středověku. Praha: Argo.

Plicka, Karel - Volf, František. 1960. Český rok v pohádkách, písních, hrách a tancích, ř́kadlech a hádankách. Zima. Praha: Státní nakladatelství krásné literatury, hudby a umění.

Sennett, Richard. 1977. The Fall of Public Man. New York: Knopf.

Solomon, Thomas. 2006. Dueling Landscapes, Singing Places and Identities in Highland Bolivia. In: Post, Jennifer C. (ed.): Ethnomusicology, A Contemporary Reader. London: Routledge: 311-328.

Stavělová, Daniela. 2005. The Dancing Poeple - Status, Identity, Integrity. In: Dunin, E. I. - Wharton, A. von Bibra - Felföldi, L. (eds.): Dance end Society. Dancer as a cultural performer. Budapest: Akadémiai Kiadó, European Folklore Institute.

Stavělová, Daniela. 2006. Doudlebská masopustní koleda: tanec jako text. Národopisná revue 16: 28-37.

Stavělová, Daniela. 2008. Červená růžičko, proč se nerozvijišs. Doudlebská masopustní koleda: tanec, identita, status a integrace. Multimediální studie. Praha: Etnologický ústav AV ČR, v. v. i.

Sušil, František. 1859: Moravské národní písně s nápěvy do textu vřaděnými. Brno: K. Winiker.

Šubrt, Jiří - Pfeiferová, Štěpánka. 2010. Kolektivní pamět jako předmět historicko-sociologického bádání. Historická sociologie 1: 9-29.

Tappert, Wilhelm. 1890. Wandernde Melodien. Leipzig: List \& Francke. 
Thořová, Věra. 2009: Lidové písně z Havlíčkobrodska, Havlíčkův Brod: Muzeum Vysočiny.

Thořová, Věra - Traxler, Jiří - Vejvoda Zdeněk. 2011. Lidové písně z Prahy ve sbírce Františka Homolky. Díl I. Praha: Etnologický ústav AV ČR, v. v. i.

Thořová, Věra - Traxler, Jiří - Vejvoda Zdeněk. 2013. Lidové písně z Prahy ve sbírce Františka Homolky. Díl II. Praha: Etnologický ústav AV ČR, v. v. i.

Tomeš, Josef. 1977. Společenská funkce lidových obřadů a obyčejů a její změny v životě současných generací. In: Premeny ludových tradícií v súčasnosti. Československo. Veda: Bratislava: 127-135.

Turner, Victor W. 2004. Průběh rituálu. Struktura a antistruktura. The Ritual Process: Structure and Anti-Structure by Victor Turner. Computer Press: Brno.
Válka, Josef. 2000. Homo festivans. In: Bůžek, Václav - Král, Pavel (eds.): Slavnosti a zábavy na dvorech a rezidenčních městech raného novověku. Opera historica 8: 5-19.

Vančík, František. 1969. Kalendářní obyčeje z jihočeského Soběnova. Masopust. Opera Ethnologica 4. Praha: ÚEF ČSAV.

Whyte, Wiliam H. 2001. The Social Life of Small Urban Spaces. New York: Project of Public Spaces.

Zíbrt, Čeněk. 2006. Veselé chvíle v životě lidu českého. Praha: Vyšehrad. 


\section{Příloha}

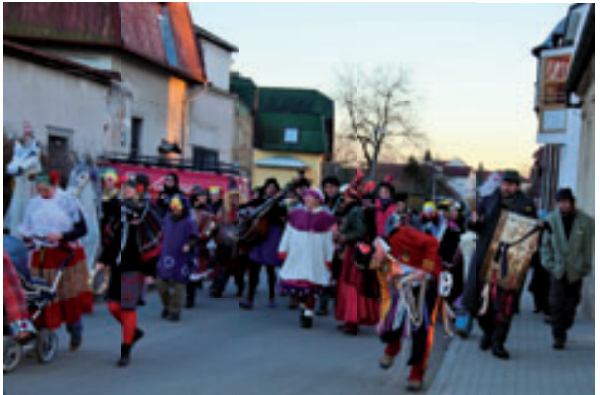

Páteční obchůzka v Roztokách

The Friday carnival parade in Roztoky, 2014

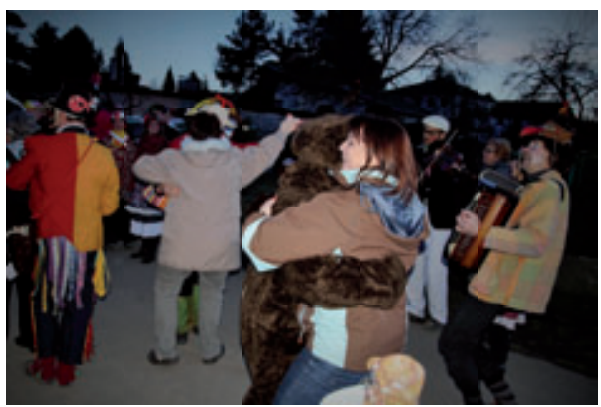

Tanec před navštíveným domem

Dance with householders, Roztoky 2014

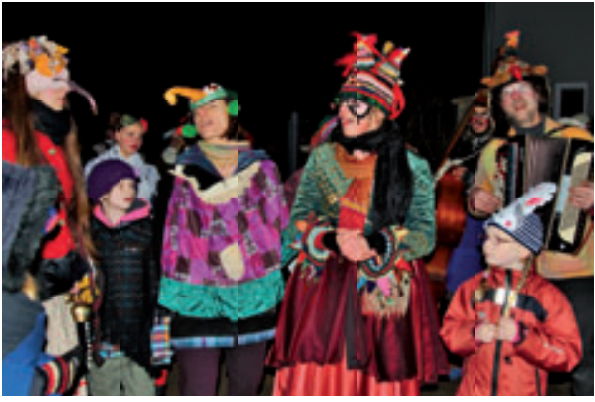

Páteční obchůzka v Roztokách vedená emeritní královnou The Friday carnival parade in Roztoky led by the emerita Queen, 2014

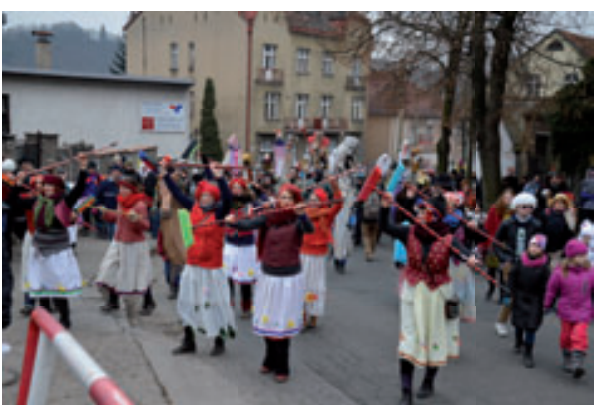

Sobotní průvod z Roztok do Únětic vedený ometačkami The Saturday carnival parade from Roztoky to Únětice led by “sweepers", 2015

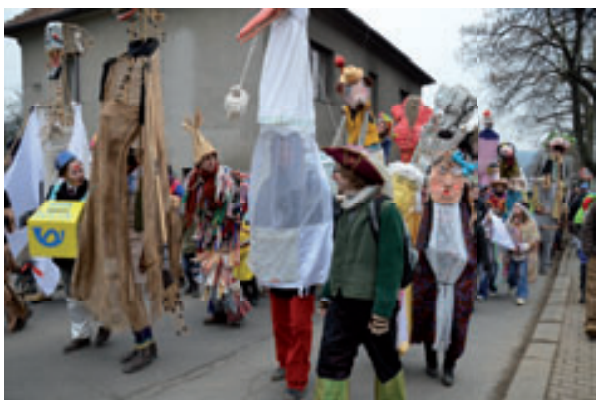

Masky v sobotním roztockém průvodu Masks in the Saturday carnival parade in Roztoky, 2015 a Úněticemi s muzikou v čele The Saturday carnival parade between Roztoky to Únětice led by a music band, 2016 


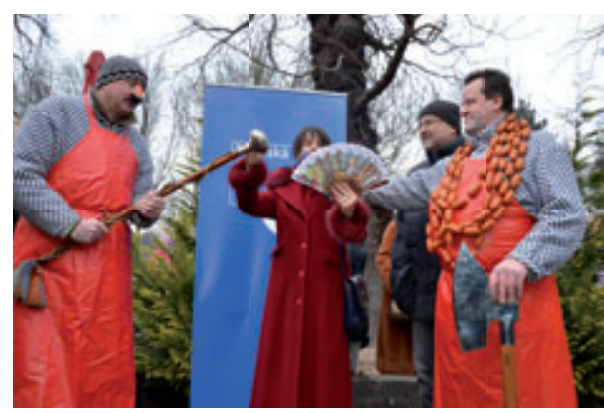

Předávání masopustního práva místostarostkou v Břevnově

The attributes of the mayor's power shared with the vice mayor in Břevnov, 2015

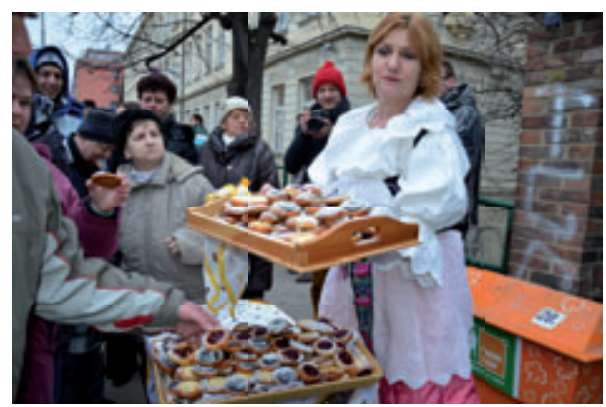

Pohoštění před břevnovským pekařstvím Refreshments in front of the Břevnov baker's, 2015

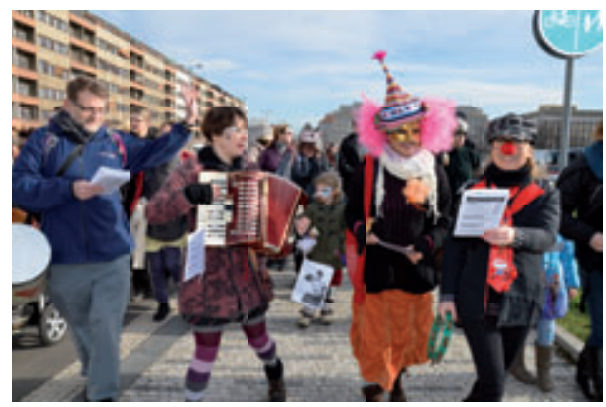

Letenský masopustní průvod vedený príležitostně sestavenou kapelou The carnival parade in Letná led by an occasional music band, 2016

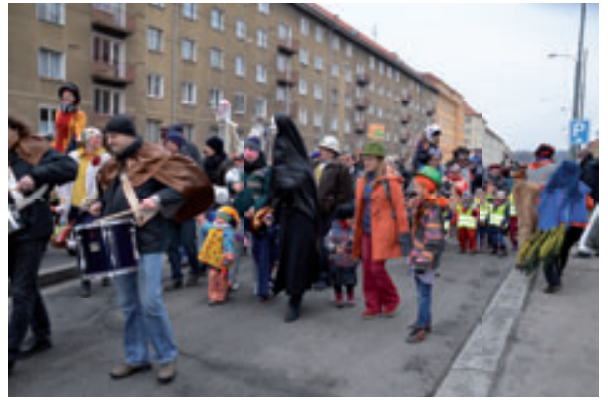

Břevnovský masopustní průvod

The carnival parade in Břevnov, 2015

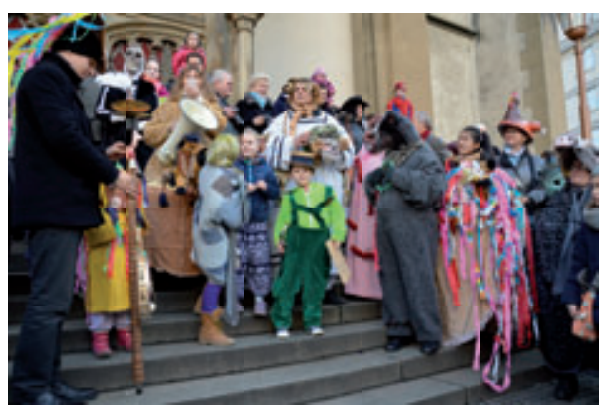

Zahájení masopustního průvodu na Letné starostou v roli Bakcha Inauguration of the carnival parade by the mayor as a Bakchus in Letná, 2016

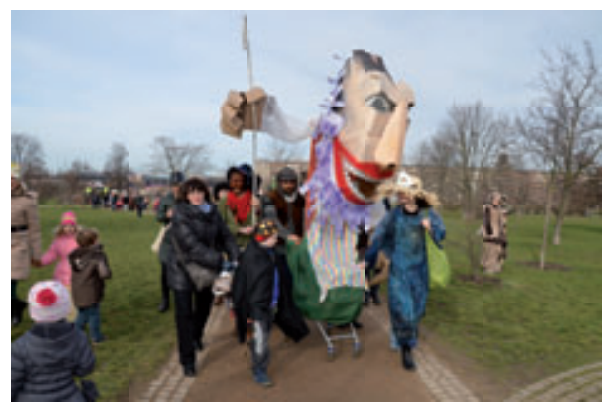

Průvod Letenskými sady mírící do Národního zemědělského muzea The parade through the Letná park to the National Muzeum of Agriculture, 2016 


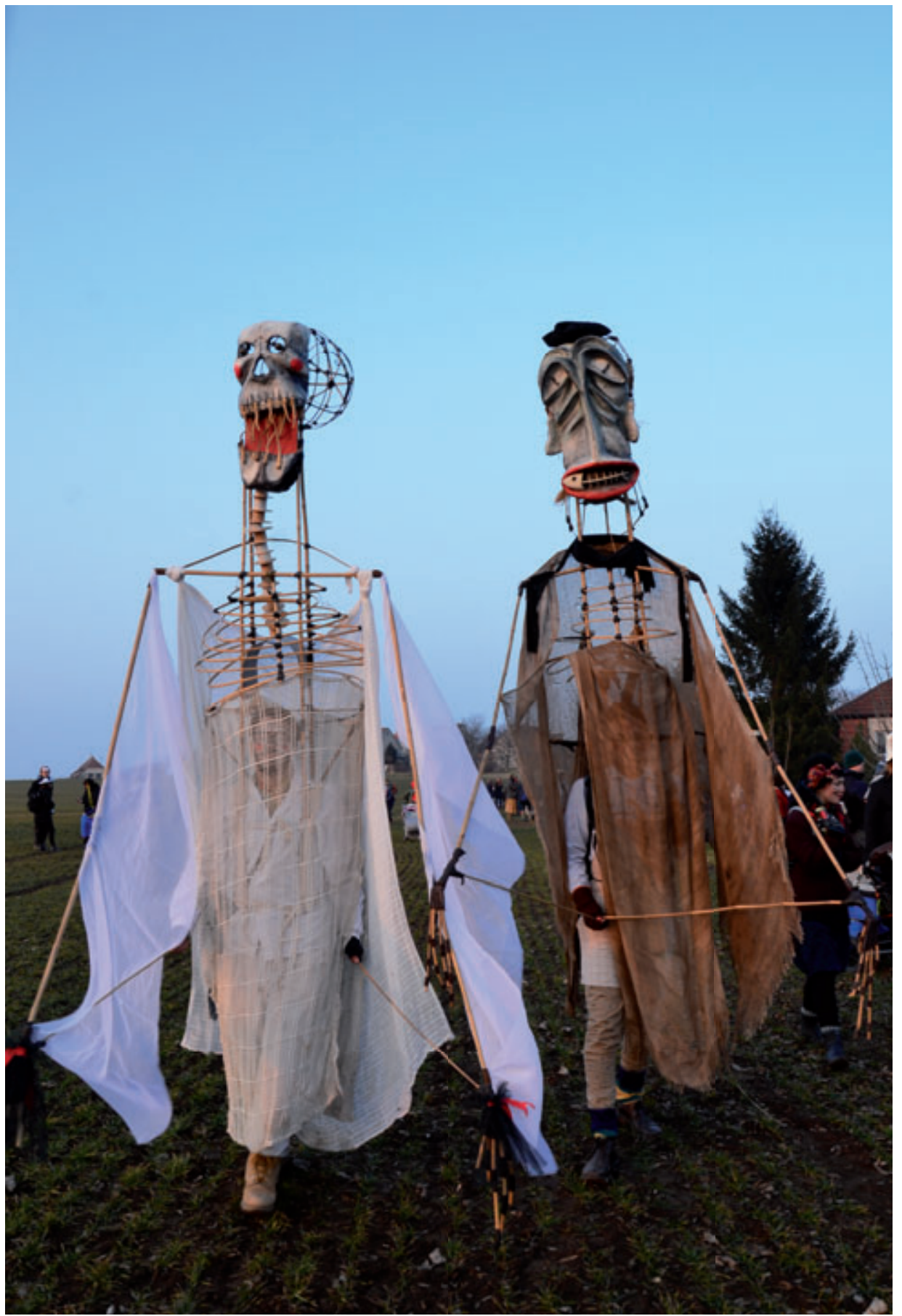

Obří loutky charakterizují roztocký masopust

Giant puppets characteristic for the Roztoky carnival, 2015 


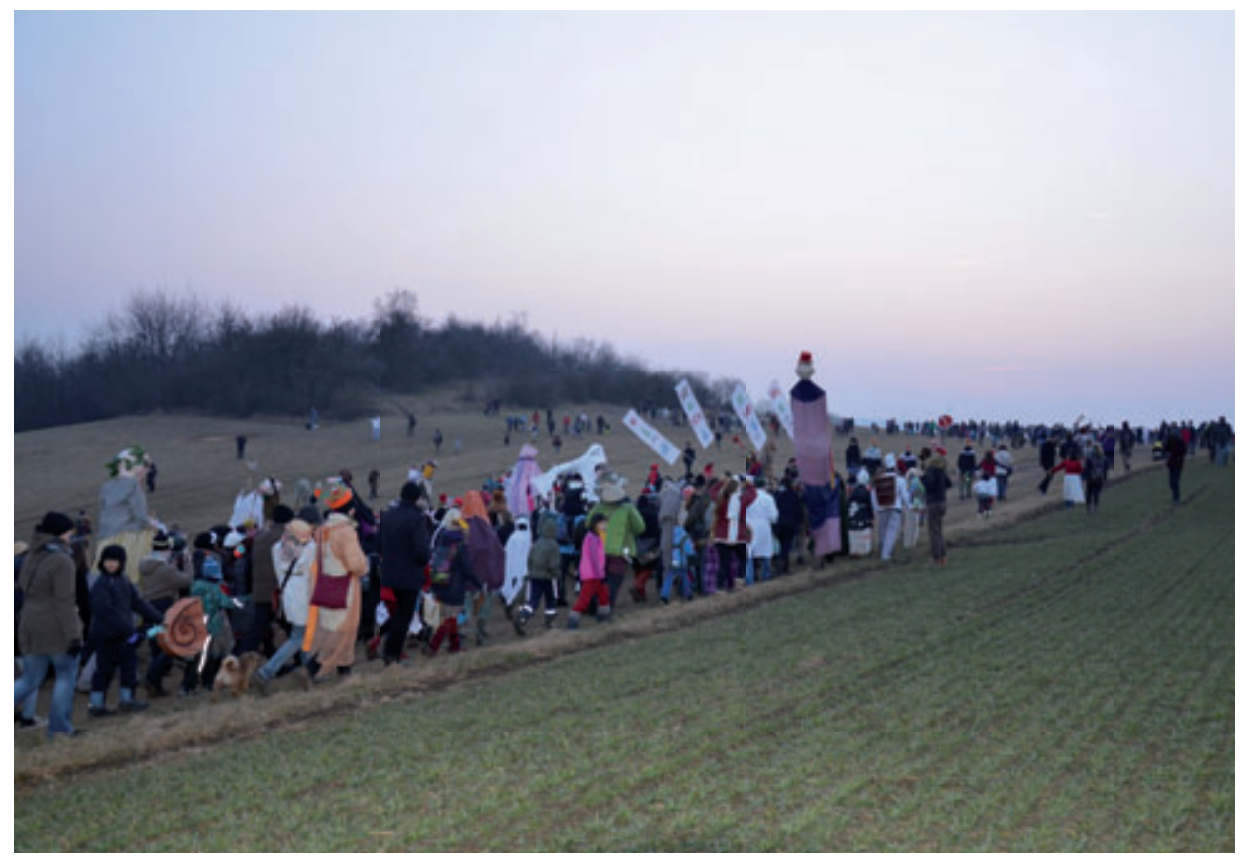

Setkání masopustních průvodů na Holém vrchu

The meeting of the carnival parades on the Holý hilltop, 2014

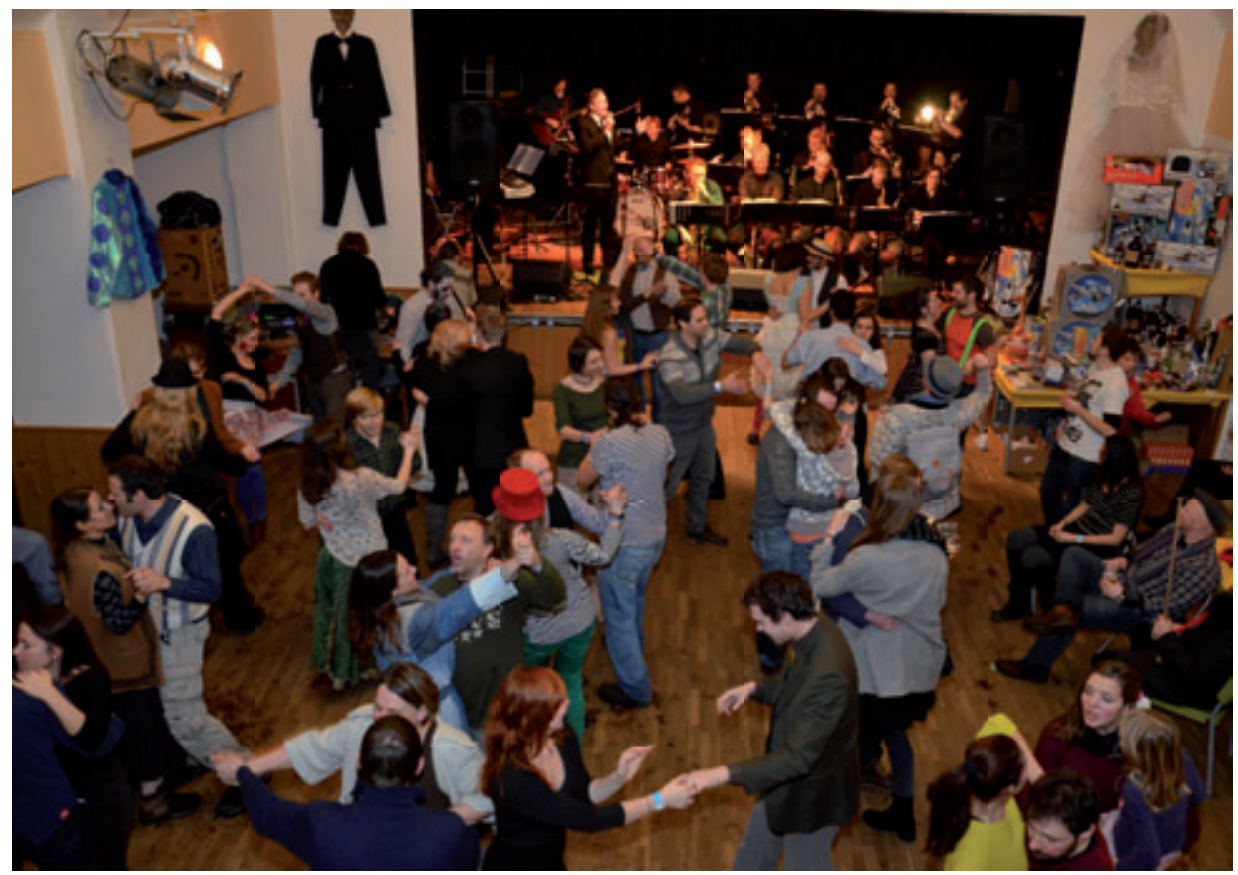

Taneční zábava v únětické Sokolovně The dance event in the Sokol's pub in Únětice, 2014 


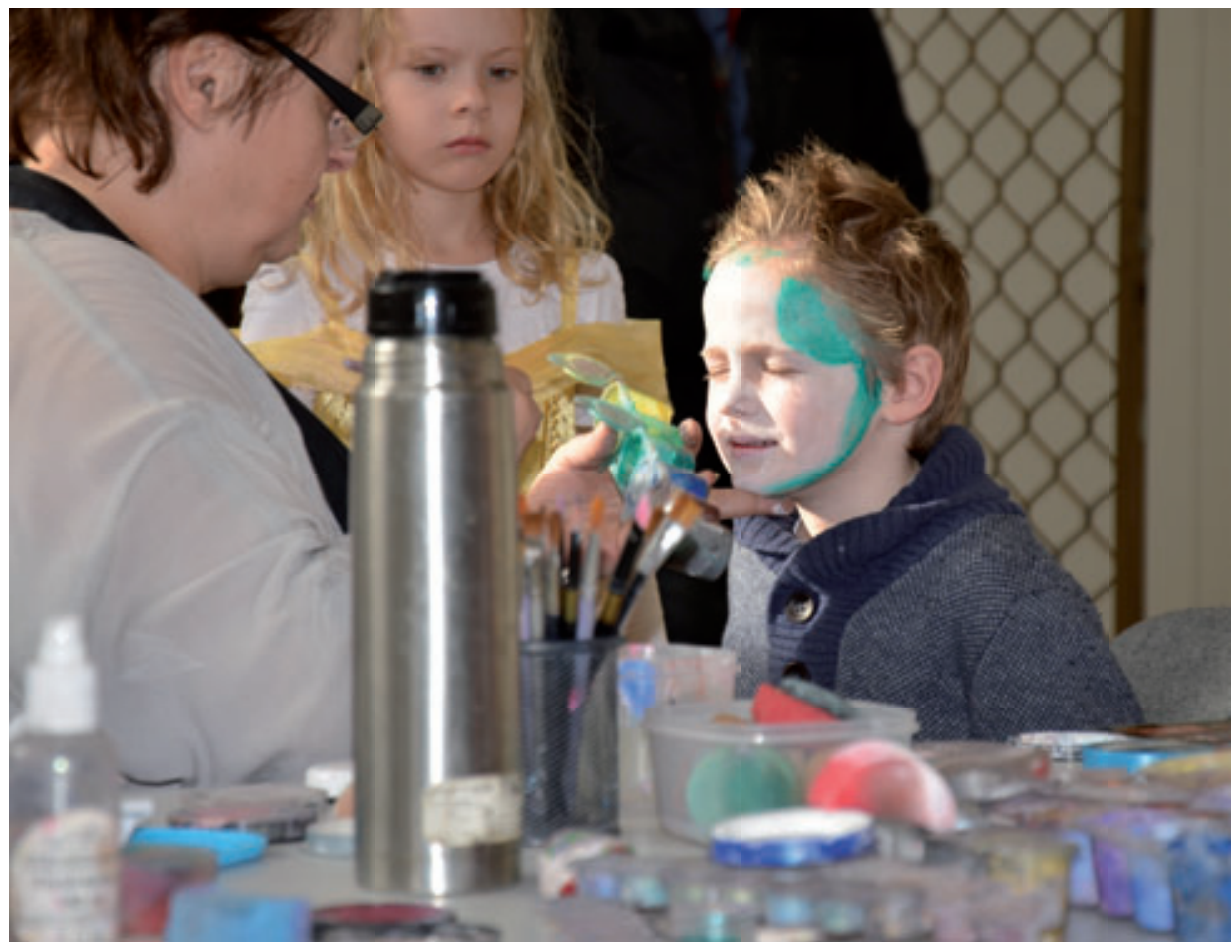

Maskování na Letné Painting a mask, Letná, 2016

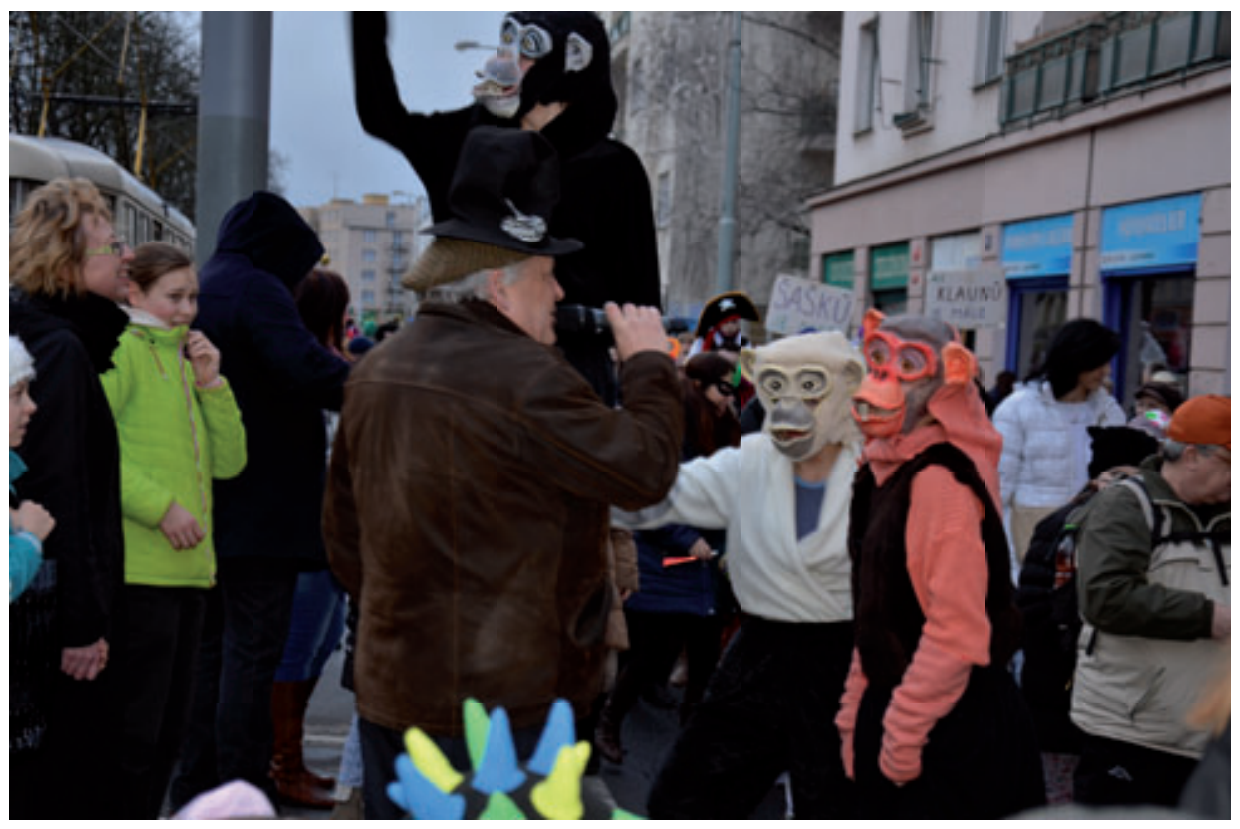

Břevnovská satira Břevnov satire, 2016 


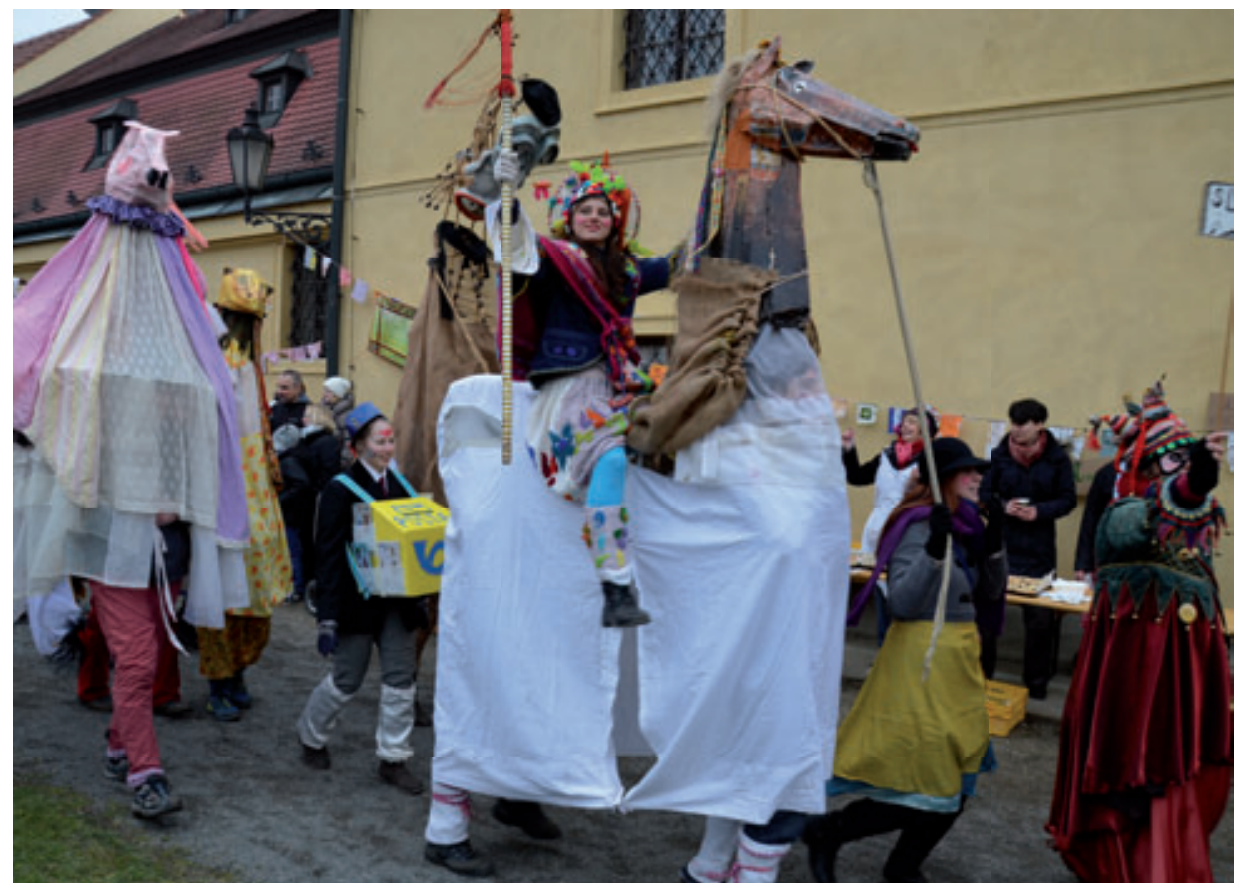

Roztocká královna masopustu na klibně a v doprovodu emeritní královny The Queen of the carnival riding on a "horse" accompanied by the emerita Queen in Roztoky, 2015 